\title{
François Mauriac: novelista y apologeta de la fe. A los 50 años de su fallecimiento
}

\author{
François Mauriac: Novelist and Apologetist of the Faith. \\ 50 Years after his Death
}

\author{
Andrés Francisco Rodríguez Quesada ${ }^{1}$ \\ Centro de Estudios Eclesiásticos de Almería \\ andres.rodriguez@diocesisalmeria.com
}

\begin{abstract}
Resumen: François Mauriac desarrolló fundamentalmente su producción literaria en la primera mitad del siglo pasado, un periodo marcado por las dos Guerras Mundiales en una Francia en creciente proceso de secularización. Así las cosas, con motivo del cincuenta aniversario de su fallecimiento la pretensión de este trabajo es hacer emerger la figura de Mauriac como apologeta quien, desde el ámbito literario, defendió algunos de los principales postulados católicos cuestionados por el alma moderna. En efecto, el premio Nobel de literatura pertenece a esa constelación de autores católicos que, profundizando en las raíces del Cristianismo, intentan dar una salida a la crisis de la Modernidad, cimentada fundamentalmente en el positivismo y el materialismo. De hecho, veremos cómo plantea el problema del mal en el mundo y la solución al mismo desde el ámbito de la caridad por medio de mártires inmolados. Asimismo, asistiremos a la crítica sistemática del novelista francés contra el antitestimonio cristiano o contra el fariseísmo religioso como elementos clave de su pedagogía apologética.
\end{abstract}

Palabras clave: Mal, pecado, mártires, expiación vicaria, apologética pedagógica, providencia divina, testimonio, fariseísmo.
Abstract: François Mauriac developed most of his literary production in the first half of the last century, a period marked by the two World Wars in a France in an increasing process of secularization. Thus, on the occasion of the fiftieth anniversary of his death, the aim of this work is to bring up the figure of Mauriac as an apologist who, from the literary sphere, defended some of the main Catholic postulates questioned by Modernism. Indeed, the Nobel Prize belongs to that plethora of Catholic authors who, delving into the roots of Christianity, try to find a way out of the crisis of Modernity, based on Positivism and Materialism. In fact, we will see how he poses the problem of evil in the world and the solution to it from the field of charity through the immolated martyrs. We will also attend the systematic criticism of the French novelist against Christian's bad example or against religious Pharisaism as key elements of his apologetic pedagogy.

Keywords: Evil, sin, martyrs, vicarious atonement, pedagogical apologetics, divine providence, testimony, Pharisaism. 


\section{INTRODUCCIÓN}

A lo largo de la historia han aparecido audaces novelistas cristianos que, como François Mauriac, han intentado defender la fe desde el ámbito de la literatura. Él se situó en el tránsito del siglo XIX al XX, en una Francia en creciente proceso de secularización. ${ }^{2}$ En aquellos momentos tumultuosos, frente a los que pretendieron recluir la religión al ámbito de lo privado, Mauriac le dio plena visibilidad por medio de su ingente producción literaria. ${ }^{3}$ Toda ella estaba encaminada a la defensa de la religión frente a los que la cuestionaban o directamente la ignoraban.

Ahora bien, ¿cuál era el origen y la fuente de ese interés apologético? Muy probablemente la raíz puede ser situada en la fortaleza de su fe en Cristo que, como una corriente de agua subterránea, fertilizaba los campos que la razón ilustrada había dejado baldíos. Un elemento evidente de esa fe en el Dios hecho hombre aparece en su "Vida de Jesús" donde deja claro su amor, su afecto a la persona de Jesús:"una confianza, una fidelidad, a pesar de tantas infidelidades". ${ }^{4}$

Mauriac es un hombre práctico que huye de la especulación abstracta. ${ }^{5}$ Con todo, no pretende desacreditar la dimensión racional y doctrinal

1 Este trabajo ha sido realizado con la ayuda del Centro Español de Estudios Eclesiásticos anejo a la Iglesia Nacional Española de Santiago y Montserrat en Roma en el marco de los proyectos de investigación del curso 2019-2020.

2 Una de las obras más completa y prestigiosa que estudia el trabajo de los novelistas del siglo XX desde el punto de vista tanto de su fe como de su compromiso cristiano es la del belga Charles Moeller publicada en las últimas décadas del siglo pasado: Charles MoelLer, Literatura del siglo XX y Cristianismo, 6 vols., Madrid, Gredos, 1981-1995. También se pueden consultar a este respecto obras más recientes como: Enrique SÁNCHEz CuESTA, El resurgimiento católico en la literatura europea moderna [1890-1945], Madrid, Encuentro, 2014; Salvador BRUNA ReVERTER, El Sofriment Vicari en Graham Greene i en els Escriptors Francesos del Catholic Revival, [tesis doctoral inédita], Barcelona, 2014; Id., "El sofriment vicari a Sous le soleil de Satan (1926), La joie (1928), Journal d'un curé de campagne (1936) i Dialogue des carmélites (1948), de Georges Bernanos", Lletres de filosofía i humanitats IV (2012) 73-116.

3 Enrique Sánchez Cuesta constata la crisis del alma moderna - fundamentalmente del positivismo - a la que se busca dar respuesta desde el ámbito católico. Cf. SÁNCHEZ Cuesta, El resurgimiento católico en la literatura europea moderna, 22: Un catolicismo que buscará su inspiración en el periodo más prístino de la fe - la primitiva cristiandad y los Padres de la Iglesia—, así como en el momento de mayor lustre —la Edad Media y la escolástica tomista".

4 François MAURIAC, "Prefacio", en ID., Obras completas, vol. III, Barcelona, Plaza \& Janes, 1961, 10.

5 "Es un hecho que todo razonamiento teológico se vuelve, muy pronto, una prueba para mi fe mientras que ella se alimenta de la oración de los místicos". ID., La piedra del escándalo, Buenos Aires, Troquel, 1955, 86. 
de la fe, ${ }^{6}$ pero subraya el carácter experiencial de la misma. De hecho, llega a sostener:" alcanzo a Dios en mí y en los demás por la experiencia que poseo de él y por la que ellos tienen de Él". ${ }^{7}$ De ahí el lugar preeminente que el testimonio cristiano - o su contrario, el antitestimonio-va a ocupar en su obra.

La pretensión del trabajo que ahora presentamos con motivo del cincuenta aniversario del fallecimiento de Mauriac consiste en penetrar en su obra para descubrir cómo expone y defiende algunos de los tópicos religiosos más relevantes. Entre ellos podemos destacar lo que el propio autor denomina como "el misterio del mal" y las posibles salidas al mismo. Él está firmemente persuadido de que Dios no abandona a ninguno de sus desesperados. Más aún, actúa en su vida de múltiples formas entre las que destaca la intervención por medio de víctimas-mártires. A partir de ahí, nos proponemos hacer emerger la figura de un laico dispuesto a defender la fe que profesa desde el ámbito de la literatura.

\section{EL NOVELISTA ANTE EL “MISTERIO DEL MAL”}

Maritain, en Arte y Escolástica, aborda el problema del mal en el mundo y la responsabilidad del novelista para con el público. Según él, ante una cuestión tan acuciante, el novelista está llamado a crear experiencias vitales con integridad, autenticidad y realismo de forma que su fuerza expositiva sea capaz de mover a la gente hacia Dios. ${ }^{8}$ Maritain está convencido de que la obra de arte no puede ser un fin en sí misma, sino un medio para alcanzar algo más amado: Dios. ${ }^{9}$ Por medio de las experiencias vitales el novelista deberá presentar las verdades universales que desde un prisma cristiano iluminen la entera vida del hombre huyendo de aquello que sea susceptible de engendrar el mal. ${ }^{10} \mathrm{~A}$ tal efecto el artista, desde sus más profundas convicciones, deberá ser consciente de ciertos elementos connaturales al hombre como son sus potencialidades o los factores limitadores de las mismas. ${ }^{11}$ En este contexto es donde podemos situar a François Mauriac.

\footnotetext{
6 Cf. Ibid., 86ss.

7 Ibid., 87.

8 Cf. Jacques Maritain, Arte y escolástica, Buenos Aires, La Espiga de Oro, 1958, 93ss.; cf. Ibid., 215ss. Según Maritain, solo el novelista cristiano puede ser considerado como

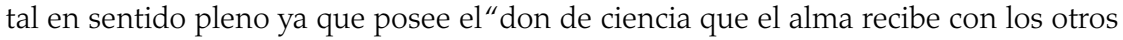
dones de la gracia": Ibid., 216.

9 Cf. Ibid., 93ss.

10 Cf. Ibid., $94 \mathrm{ss}$.

11 "El único problema para el artista consiste en no ser débil; tener un arte que sea lo bastante robusto y lo bastante recto para dominar en cualquier caso su materia sin
} 
Mauriac se sumerge plenamente en el mundo del mal, del sufrimiento y del pecado. Lo que realmente le preocupa es plasmar en personajes y vidas concretas las inmundicias humanas y sus posibilidades de redención, alejándose de disquisiciones metafísicas. ${ }^{12}$ De esta forma, pretende desarrollar una especie de apologética pedagógica con la que ir transmitiendo sus principales convicciones religiosas a los destinatarios de sus escritos. Ahora bien, el peligro de todo ello puede ser dúplice. Por un lado, uno se puede inmiscuir tanto en el campo del dolor, del sufrimiento o del mal que se pierda la objetividad necesaria, extremo este del que se le ha acusado a nuestro autor. ${ }^{13}$ Por otro, al querer presentar con tanto realismo el mundo del pecado y del mal ¿no se correría el riesgo de potenciar aquello que se quiere combatir? ${ }^{14} \mathrm{~A}$ lo cual Mauriac respondería afirmando que" cualquier cosa es mejor que la falsificación de la realidad, y que la inquietud, y la turbación nacidas de la verdad desbrozan muchas veces el camino hacia la Gracia". ${ }^{15}$ Además, "la historia humana contada por un novelista católico no puede resultar idílica ya que le está prohibido desconocer el misterio del mal". ${ }^{16}$

Mauriac es plenamente consciente de la dificultad de escribir desde el punto de vista católico en un ambiente profundamente secularizado y, más aún, sobre un tema tan delicado como el del mal. Con todo asume los riesgos y se hunde en él, retratando a seres infelices y malqueridos que no son otra cosa que un grito desesperado a Dios. El francés no escribe desde un punto de vista teológico ni filosófico, sino como novelista católico comprometido en la defensa del Dios cristiano. ${ }^{17}$ En efecto, en todas sus obras parece que Mauriac tuviera como pretensión principal de la pormenorización del mundo del mal el fortalecimiento de la fe de sus lectores, así como el aleccionamiento de los cristianos incautos que deciden jugar en el campo de juego del príncipe de las tinieblas, creyéndose

perder nada de su elevación ni de su pureza, y para no tener en vista [...] otra cosa que el bien de la obra": Ibid., 96.

12 Cf. François Mauriac, "Prefacio", en Id., Obras completas, vol. I, Barcelona, Plaza \& Janes, 1962, 17.

13 Cf. A. A. De Vitis, "The Catholic as novelist Graham Greene and François Mauriac", en Robert O. Evans, Graham Greene: Some Critical Consideration, Kentucky, University of Kentucky, 2009, 212-215.

14 Maritain afirma que cuanto más se desciende en la miseria humana más se"exige del novelista virtudes sobrehumanas": MARITAIN, Arte y escolástica, 215.

15 Enrique Sordo, "Prólogo", en François Mauriac, Obras selectas de premios Nobel: François Mauriac 1952, Barcelona, Planeta, 1987, III.

16 François Mauriac, "Discurso pronunciado por F. Mauriac el 10 de diciembre de 1952 en Estocolmo tras recibir el Premio Nobel de Literatura", en François Mauriac, La piedra del escándalo, Buenos Aires, Troquel, 1955, 110.

17 Cf. DeVitis, "The Catholic as novelist", 126ss. 
más listos que él. Por eso, al comienzo de la confesión en Los ángeles negros pone en boca de Gabriel Gradére una admonición contra un posible escándalo por bucear en las entrañas del mal:"Y, sobre todo, no tema ser escandalizado. Esta historia tiene poder para fortificar su fe en el mundo invisible a que sirve, pues también es posible penetrar en lo sobrenatural por lo rastrero" 18 .

Ante lo que denomina "el misterio del mal", ${ }^{19}$ Mauriac no pretende dar una respuesta a la aporía de la razón, por otro lado, insoluble; ${ }^{20} \mathrm{ni}$ lo relaciona con la existencia o no de Dios, extremo que da por descontado. Al contrario, presenta una suerte de salida tangencial de corte fundamentalmente pragmático y experiencial que supone un cambio de planos. El francés concibe el mal en un sentido muy agustiniano"lo que daña" ${ }^{\prime 21}$ al hombre, ya sea considerado individual o colectivamente. De hecho, en su mente se encuentra el hecho de que el mal o el pecado -que para él suelen aparecer de la mano- destruyen tanto al hombre como a sus relaciones con otros similares y con Dios. Pues bien, ante ese mal no habría más que dos alternativas: o se niega, evadiendo absurdamente el problema, o se asume"tal como se manifiesta en nosotros y fuera de nosotros en nuestra propia historia, la de nuestras pasiones, y en la historia exterior" ${ }^{22}$ Él, evidentemente, prefiere la segunda opción. ${ }^{23}$ Por eso, no trata de justificar racionalmente la existencia de Dios ni de sus omniatributos ante el problema del mal, pues "la respuesta que se nos escapa [racionalmente] pertenece a un orden que no es el de la razón sino el de la caridad" ${ }^{24}$ En este sentido, lo que pretende es, partiendo

18 Mauriac, Los ángeles negros,"Prefacio", en ID., Obras completas, I, 1060ss.

19 Ibid., 1163.

20 El problema fue planteado en la Antigüedad clásica, siendo su autoría tradicionalmente atribuida al filósofo griego Epicuro. Este habría propuesto el famoso dilema acerca de la coexistencia de Dios — con sus omniatributos divinos- y el mal. O bien Dios no existe, o es imposible que se conjuguen en él las cualidades de omnipotencia y omnibenevolencia. Si Dios es bueno y permite el mal, no es omnipotente. Si Dios es omnipotente, al existir el mal deberemos concluir que no es bueno. Ahora bien, si puede y quiere, como es lógico por ser Dios, ¿de dónde procede el mal? Cf. Theodor W. Adorno, Dialéctica negativa, Madrid, Akal, 1975, 315-319.

21 De moribus manichaeorum, II, 3, 5.

22 MAURIAC, "Discurso pronunciado por F. Mauriac el 10 de diciembre de 1952", 110.

23 "Muy caro pagamos para rendirnos a la evidencia de que el mal es el mal (nosotros, los que vivimos bajo un cielo en el que aún hay vestigios del humo de los crematorios). Hemos visto con nuestros propios ojos cómo fueron devorados millones de inocentes y hasta niños. Y sigue la misma historia. [...] miramos con terror cómo se contrae a nuestra vista [...] el espacio en que el hombre sigue gozando de los derechos del hombre, en que el espíritu humano permanece libre": Ibid., 111. 
de la constatación de la existencia del mal que nos rodea y que anida en nuestra alma, analizar qué posibilidades y qué riesgos penden realmente sobre el hombre de a pie.

En cuanto al origen del mal, Mauriac es partidario de la doctrina tradicional que situaba en el mal empleo de las capacidades naturales la fuente de la corrupción y de la perdición. Ello lo expresa de nuevo por boca de Gabriel Gradère. Allí, al intentar remontarse hasta los orígenes de su situación, perdida lo halla en el mal uso de los dones con que Dios lo proveyó. ${ }^{25}$ Más aún, el propio Alain Forcas — protagonista de Lo que estaba perdido y de Los ángeles negros - recuerda que:

En nosotros llevamos la mentira y el pecado; es don divino amar a Dios y su amor nos recompensa de lo que su amor nos ha otorgado. Pero si Él empieza por el bien, nosotros comenzamos por el mal. Dios obra en nosotros y con nosotros cada vez que hacemos el bien; en cambio, cada acción mala únicamente a nosotros se debe. En lo que al mal se refiere somos dioses en cierta manera... ${ }^{26}$

Con todo ello en la trastienda, el francés está firmemente persuadido de que en el peor criminal subsisten siempre algunos elementos del santo que habría podido ser. Mauriac no da por perdido a ninguno de sus "monstruos"ya que en lo más profundo de su ser"presienten que tienen alma", ${ }^{27}$ además," todos tienen conciencia de que una parte de su ser conoce el mal, y que podría no cometerlo". ${ }^{28}$ Sus"monstruos buscan a Dios entre gemidos ${ }^{\prime \prime 29}$ y en esa búsqueda se encuentra su tabla de salvación.

Todo ello se ve reforzado por la convicción del francés de que la respuesta al mal no procede del ámbito racional sino del de la caridad."Dios es amor" (1 Jn 4,8.16) y, como recoge en el discurso que dio con motivo del Nobel de literatura," nada le es imposible al amor viviente, ni siquiera

25 “Lo que decidió mi vida actuó desde mi niñez. Sí, por mucho que me remonte en el pasado, siempre llego a la conclusión de que yo era un ser agradable; o más exactamente, mi fisonomía era plácida y yo me aprovechaba de ello. [...] Es preciso aclarar y concretar lo que ha producido mi aparente triunfo, lo que, en realidad, me ha perdido. [...] El deseo de utilizarlo fue instintivo primero, y más consciente después": ID., Los ángeles negros, 1061. Ya en su más tierna juventud el pequeño Gabriel utilizó sus encantos para aprovecharse de las primas Du Buch cuya familia sustentaba sus estudios. Más aún, las llegó a corromper poniéndolas en la tesitura de escoger entre sus principios religioso-morales y la atracción física que el pequeño despertaba en ellas. Cf. Ibid., 1068.1073.

26 Ibid. 1164.

27 ID., “Discurso pronunciado por F. Mauriac el 10 de diciembre de 1952”, 108.

28 Ibid.

29 ID., "Prefacio", en ID., Obras completas, I, 18. 
el atraer todo hacia sí" ${ }^{30}$ Por encima de cualquier raciocinio, Irene —una de las protagonistas de Lo que estaba perdido - llega a la conclusión de que en la vida creemos que lo importante es comprender el porqué de las cosas, cuando en verdad estamos hechos no para comprender, sino para amar. ${ }^{31}$ Es ese amor el que le abre a los otros y deja la puerta entreabierta al Infinito. De hecho, será el amor manifestado por personas concretas la forma en que Dios actuará rescatando a los monstruos de Mauriac.

En el otro extremo, el novelista galo está convencido de que en el ser más puro, más inocente asoman espantosas posibilidades ante la fuerza de las pasiones y las tentaciones de la vida. ${ }^{32}$ Una u otra salida dependerán para Mauriac no solo de las fuerzas y de la voluntad del hombre, sino, sobre todo, de la actuación de la gracia divina en sus múltiples variantes. Ahora bien, aunque su concurrencia es decisiva, no todo se puede dejar a la acción de la gracia, ya que el hombre debe esforzarse por ir recreándose en cada momento so pena de continuar siendo un "monstruo". ${ }^{33} \mathrm{El}$ propio autor lo expresa de manera lapidaria:"nuestra vida vale lo que nos ha costado en esfuerzos". ${ }^{44}$ De esta manera, Mauriac intenta equilibrar las dimensiones objetiva y subjetiva de la redención, ya que el hecho de "que la salvación sea gracia no supone la huida del hombre respecto de su propia responsabilidad". ${ }^{35} \mathrm{Al}$ contrario, la salvación es don de Dios al hombre y tarea de este. En palabras de González Faus:"no hay salvación si no viene de fuera, no hay salvación si no brota de dentro" ${ }^{36}$

La ambivalencia entre el santo y el pecador como núcleo de posibilidades aparece en diversas obras, pero quizás en la que mejor queda perfilada es en Los ángeles negros. Allí, para plasmarlo nítidamente el novelista emplea dos protagonistas como modelos. Por un lado, Gabriel Gradère que, como recoge el propio Mauriac, es un corruptor ${ }^{37} \mathrm{y}$ un"pervertido desde la infancia, sacrílego, proxeneta, encubridor, ladrón, [...] asesino que no deja de ser, a pesar de todo, un hombre espiritual".$^{38}$ Llamado y vocacionado desde su más tierna infancia rehúye la llamada del Señor para aventurarse por caminos de difícil retorno. Aun así, por

\footnotetext{
30 ID., “Discurso pronunciado por F. Mauriac el 10 de diciembre de 1952”, 112.

31 Cf. ID., Lo que estaba perdido, en ID., Obras completas, I, 1010.

32 Cf. ID., "Prefacio", en ID., Obras completas, I, 17.

33 Cf. Sordo, "Prólogo", IV.

34 MaURIAC,"El joven", en ID., Obras completas, II, Barcelona, Plaza \& Janés, 1962, 1178.

35 Víctor Montoya, Cur Deus Homo? Una respuesta desde la soteriología española contemporánea, Almería, Instituto de Estudios Almerienses, 2013, 95.

36 Cf. José Ignacio González Faus, La Humanidad Nueva, II, Santander, Sal Terrae, 1974, 554.

37 Cf. Mauriac, Los ángeles negros, 1068. 1073.

38 ID., "Prefacio", en ID., Obras completas, I, 17.
} 
envilecido o mancillado que se encuentre, late un fondo espiritual que lo lleva a encaminarse hacia su Creador mediante obras de caridad. Por eso, en cierto momento ante la turbación de Adile — que se creía corruptora del joven Gradére- Gabriel reconoce que el adulto que había corrompido a la joven era él. ${ }^{39} \mathrm{Tal}$ es la importancia que da Mauriac al caso que especifica el momento exacto: "Era una mañana de Semana Santa: un momento de mi vida en que no hice mal, [...] en que hice bien, en que retuve aquella alma al borde del abismo de la desesperación". ${ }^{40}$

En el otro extremo se encuentra Alain Forcas que"no es un extraño sino un paisano de la ciudad invisible", ${ }^{41}$ "hermano de una incestuosa libertina, solo consigue escapar al crimen, para el cual parecía nacido, retrayéndose del mundo, revistiéndose con el hábito del escarnio y echándose en los brazos de Dios". ${ }^{42}$ De hecho, Gabriel Gradère reconoce en él su estado de gracia y pureza no exento de tentaciones: "Tengo únicamente la certeza de que usted es el único que puede entenderme. Usted es un niño, [...] e incluso un niño de pocos años, pero con experiencia. Y adivino que, cuanto en usted fue preservado, también sufrió una asechanza" ${ }^{43}$ En este pequeño párrafo el literato francés recoge una de sus seguridades vitales: todo ser, por puro y perfecto que sea, está sometido a las fuerzas del mal y, por tanto, a sus tentaciones. ${ }^{44}$

Más aún, esta duplicidad la observamos en el propio Gabriel Gradère donde tal contradicción la consigue plasmar Mauriac en el contraste entre sus aspectos externo e interno. Él había sido dotado de un rostro angelical —con los ojos más azules que el océano— sobre el cual parecía

39 Cf. ID., Los ángeles negros, 1073.

40 Ibid

41 ID., "Prefacio", en ID., Obras completas, I, 17.

42 Ibid.

43 En la producción de Mauriac también podemos encontrar la imagen del joven y piadoso Louis Pian (cf. ID., La farisea, en ID., Obras completas, II, 626) elegido para demostrar que hasta en el alma más pura puede anidar un"nudo de víboras". De hecho, en su más tierna infancia su corazón estaba fuertemente atenazado por los celos respecto de la relación de su hermana con su amigo Jean de Mirbel (cf. Ibid., 651ss.), así como por el odio hacia su madrastra (cf. Ibid., 760). Por otro lado, conscientemente contribuyó con su pecado e imprudencia a desatar el mal a su alrededor. Un caso paradigmático de ello fue el "escándalo de los Puybaraud", lo cual lo llenó de remordimientos que le durarían hasta la madurez (cf. Ibid., 627). Aunque intentó justificar con la ignorancia la traición al Sr. Puybaraud que le había confiado una carta para su amada él "comprendía perfectamente de qué se trataba" (cf. Ibid., 627). Posteriormente, movido por los celos, insinuó a su madrastra que su amigo y su hermana lo rehuían para estar solas. Palabras que también desencadenaron toda una tormenta en la casa de los Pian y cuyas repercusiones alcanzaron al abate Calou (cf. Ibid., 670). 
que no pasaban los años. A pesar de este aspecto ideal"casi divino", desde su juventud supo aprovechar sus encantos para embaucar a incautas que caían en sus trampas amorosas. Todo ello lo condujo hacia los caminos del vicio y la perdición. De hecho, esta contradicción es la que da título a la novela: Los ángeles negros.

Mauricac enmarca todo ello entre dos elementos: por un lado, la distinción entre el pecado y el pecador, entre el error y el que yerra. ${ }^{45}$ Por otro, la atracción que sobre ciertas almas provoca el mundo de la oscuridad, extremo este que el francés presenta por boca de un anciano sacerdote: "hay almas que se empeñan en condenarse" ${ }^{46} Y$ es que el hombre se encuentra suspendido entre la nada o más bien el mal, y la salvación, entre la perdición y la gloria. En ese mismo espacio se encuentran dos fuerzas antagónicas: por un lado, el pecado y la tentación como fuerzas mundanas que atraen al hombre hacia sus instintos más bajos, los de la pura animalidad; hacia la búsqueda del placer por el placer y la satisfacción del ámbito de la sensualidad. En contra, hallamos en la obra de Mauriac la fuerza de la atracción divina representada por la gracia que actúa de muy diversas maneras en la vida de sus protagonistas. Todo ello se encamina, según la pedagogía de Mauriac, a interpelar al pecador para que reconozca su situación de caída, se levante y reoriente su vida.

Finalmente, en el marco del misterio del mal el novelista insiste en que hay que estar siempre alerta ya que el mal persiste en el mundo, sobrevive a los pecadores y anda buscando a quién devorar. ${ }^{47}$ En este sentido aparece un Mauriac bastante pesimista, aunque quizás sea, más bien, realista: "Todo se prolongaría en Andrés, en Catalina, en las criaturas que procederían de ellos, quizás interminablemente [...] La muerte no interrumpía nada de lo que los muertos habían iniciado". ${ }^{48}$ Con ello también pone en guardia ante las consecuencias remotas del mal. Ahora bien, a pesar de esto la esperanza y la confianza de Mauriac superan cualquier pesimismo:"Matilde sabía que existe otra fuerza: Adila se había salvado; la culpable criatura que la había corrompido [Gabriel] estaba ya más que a mitad del camino del cielo. Incluso en Liogeats, la humana esperanza proclamaba victoria. Había vencido el amor...". ${ }^{49}$

\footnotetext{
45 “Entonces, ¿por qué te casas conmigo? [preguntó Gabriel]

Debo hacerlo... por Andrés.

¿Ya no me amas? ¿Te repugno?

No — protestó-, solo el mal que hay en ti": ID., Los ángeles negros, 1072.

46 Ibid., 1077. 1163.

47 Cf. Ibid., 1214ss.

$48 \quad$ Ibid., 1214.

$49 \quad$ Ibid., 1215.
} 


\section{EL NIÑO, LA NATURALEZA Y LA CIUDAD COMO ALEGORÍAS DEL BIEN Y DEL MAL}

A menudo, para expresar plásticamente esta duplicidad del alma humana Mauriac recurre al rostro del niño o de personajes mayores que viven como niños. Es la imagen de la pureza y de la santidad sobre la que empieza a cernirse el riesgo del mal. ${ }^{50} \mathrm{~A}$ su vez, la imagen del niño se convierte también en prototipo de la pureza a la que todo hombre debe aspirar en la vida. Es más, para él un niño sueña en la base de todos sus libros, y en ellos no faltan los amores infantiles, los primeros besos, las primeras soledades. ${ }^{51}$ La infancia es una de las alegorías que emplea con el fin de presentar el momento en el que se va abandonando la pureza inicial para encaminarse hacia la senda del mal y del pecado; es ese paraíso que se va perdiendo para dar lugar al nudo de víboras que anida en el corazón de cada hombre.Y es que Mauriac está convencido de que nadie nace siendo un monstruo, sino que se va creando a sí mismo cuando sucumbe a las pasiones y a las tentaciones de la vida. Este movimiento lo refleja la propia Thérèse Desqueyroux: "Yo era pura, un ángel, sí; pero un ángel lleno de pasiones...". ${ }^{52}$ Otro tanto se puede decir de Luis - protagonista de Nudo de víboras - por medio de cuya vida se intenta responder a la cuestión: el pecador ¿lo es desde siempre? La respuesta es situarlo todo en un proceso que evoluciona en libertad partiendo de unas disposiciones naturales e influido por el ambiente, especialmente por el testimonio o el antitestimonio de los cristianos. ${ }^{53}$

También recurre a la imagen de la naturaleza para plasmar con destreza la bipolaridad entre el bien y el mal. De hecho, cuando habla del pecado lo sitúa en el ámbito de las olas del mar cuya espuma roza los pies de los seres puros. Con ello quiere resaltar el hecho de que nadie en este mundo está alejado de la tentación y del pecado. ${ }^{54}$ Dibuja también el pecado por medio de la imagen del lodo que todo lo envilece. ${ }^{55}$

50 “Tenemos una sola vida: Tal vez Gradère sería perdonado, pero no volvería a ser el niño que se despierta una mañana de vacaciones, que se descalza para sentir en las plantas la quemadura de la arena y cuyas morenas piernas dividen la linfa del Balion". Ibid., 1207; cf. Ibid., 1059.

51 Cf. ID., "Discurso pronunciado por F. Mauriac el 10 de diciembre de 1952", 110. Se pueden ver diversos pasajes donde pone la figura del "niño" como ejemplo de pureza y ausencia de maldad. Cf. ID., El fin de la noche, en ID., Obras completas, I, 904. 907; cf. ID., Lo que estaba perdido, en ID., Obras completas, I, 972.

52 ID., Thérèse Desqueyroux, en ID., Obras completas, I, 633.

53 Cf. ID., Nudo de viboras, en ID., Obras completas, I, 1270.

54 Cf. ID., Los ángeles negros, 1060.

55 "Acaso haya presentido que es usted [...] capaz de comprender el poder de envilecimiento que obra constantemente en ciertos seres... No se enfade. Aunque yo esté 
Mauriac juega, además, con la distinción entre la vida en la gran urbe -París, Burdeos o Lyon-frente a las pequeñas villas provincianas de Liogeats o Baluzac. La primera constituye la alegoría del pecado y del vicio: el lugar donde se desarrolla con naturalidad el "misterio del mal". ${ }^{56}$ Por el contrario, Liogeats o Baluzac son unas villas pequeñas que representan a la sociedad en su estado natural, donde lo importante son las tareas cotidianas que jalonan la jornada. Allí se abandonan las abstracciones metafísicas, las conversaciones ociosas, el placer por el placer en pro de un pragmatismo vital.

Asimismo, recurre a los signos evangélicos de la luz y el día para representar al bien y la verdad. ${ }^{57}$ Así, por ejemplo, emplea la imagen de la luz en la ventana de un castillo a oscuras contemplada desde la distancia para mostrar el hecho de que la salvación campea en medio del pecado. ${ }^{58}$ Otro tanto se puede decir de la oscuridad y la tormenta para hacer lo propio con el mal y el pecado. A los pecadores los compara con copos que se abaten en una tormenta de nieve, copos que caen inexorablemente unos sobre otros de forma infinita. ${ }^{59}$

\section{LA PROVIDENCIA DIVINA Y EL RESCATE DE LA MASA CRIMINAL POR MEDIO DE LOS INMOLADOS}

\subsection{La Gracia}

Otro de los temas destacados en la producción de François Mauriac es el constituido por la acción de Dios en la vida de sus "monstruos": 60 "sus atormentados héroes se hunden a veces en las más hondas ignominias, hasta llegar a encontrarse acorralados por el asco total de sí mismos; es entonces, si la gracia ayuda, cuando puede empezar su redención". ${ }^{61}$ Más aún, según el sentir del literato francés frente al antitestimonio de los cristianos o las desviaciones de la piedad la gracia divina puede intervenir

mancillado por el lodo y sea casi un cadáver, y usted camine sobre las olas y sus pies rocen apenas la espuma [el pecado], aun así, juraría que no le sorprenderá el desarrollo de mi existencia [...] me ofrezco a usted hasta mis entresijos": Ibid.

56 Ibid., 1063.

57 "Todos retrocedieron ante la luz, se agazaparon en espera de lo que acaso iba a surgir": Ibid., 1197.

58 Cf. Ibid., 1201.

59 Ibid., 1164.

60 En Mauriac el tema de la gracia está íntimamente unido al de la esperanza cuya manifestación es doble: por un lado, la esperanza permanente en la conversión de los pecadores; por otro, la esperanza teologal que mueve la vida de los personajes que se esfuerzan por caminar por la senda evangélica. Cf. Ibid., 1129.

61 SORdo, "Prólogo", III. 
ya que "ella actúa por debajo, como protegida por esta capa de células aparentemente muertas". ${ }^{62}$

El novelista francés plasma en sus escritos la experiencia humana del silencio divino. Su finalidad no es otra que mostrar el hecho de que, cuando aparentemente Dios guarda silencio, no se produce el abandono del desesperado. Al contrario, Dios, que no desampara a nadie, interviene en las formas más insospechadas. Una de las maneras privilegiadas por Mauriac de la actuación divina es la iluminación interna del pecador. El objetivo de esta no es otro que el que pueda tomar conciencia de su situación y cambiar de vida. Así, por ejemplo, Los ángeles negros comienza con un extenso prólogo donde Gabriel Gradère realiza una especie de confesión general destinada a ser leída por el joven pastor de almas Alain Forcas. Ello, según había establecido años antes el Mauriac de Lo que estaba perdido, suponía el mayor don que la providencia divina le había podido conceder. Allí por boca de la vieja Blénauge había dejado sentado a Hervé que el hecho de tener la posibilidad de reconocer los errores, pecados e inmundicias del pasado era un regalo de Dios y el punto de partida de un camino salvífico sin retorno:63 "el leproso que ve su llaga, ¿cómo no ha de desear ser curado?". ${ }^{44}$ Ahora, Gabriel hace lo propio por medio de una extensa misiva que no completará hasta el final de sus días cuando el sacerdote lo acoja en confesión y pueda exclamar: "ya no soy el mismo". ${ }^{65}$ De él dice el propio narrador:"aquel enemigo de las almas, aquel asesino, se dirigía en paz hacia el cielo. Iba hacia él desbordante de alegría". ${ }^{66}$

La gracia divina puede también operar en la vida de los protagonistas de Mauriac haciendo las veces de su guía y sostén. Así lo afirma sobre el protagonista de Los ángeles negros: "Estaba seguro de su victoria, a pesar de que no sabía cómo empezaría; tenía pleno convencimiento de ser dirigido, apoyado". ${ }^{67}$ Para el autor francés Dios y su gracia son más poderosos que el pecado y el mal por lo que al final siempre termina por prevalecer en nuestras vidas a condición de que se lo permitamos. ${ }^{68}$

Con todo, la forma de actuación divina más incisiva según el sentir de Mauriac es su intervención por medio de personas concretas. Es lo

\footnotetext{
62 Mauriac, La piedra del escándalo, 24. Cf. Ibid., 78.

63 Cf. ID., Lo que estaba perdido, en ID., Obras completas, 1038ss.

64 Ibid., 1039.

65 ID., Los ángeles negros, 1170.

66 Ibid., 1217; cf. Ibid., 1218.

67 Ibid., 1136.

68 Cf. Ibid., 1153.
} 
que en la obra de Mauriac podemos denominar víctimas-mártires por las que, como veremos a continuación, Dios rescata a los caídos.

\subsection{La expiación vicaria del justo}

A lo largo de la Historia Sagrada se puede constatar cómo Dios ha intervenido en favor de los justos. Dicho de otro modo, en múltiples casos Dios restituye al justo su valor tras un periodo de sufrimiento. Tal es el caso de José (Gn 37; 39-50), Jeremías; los perseguidos del libro de Daniel: Ananías, Azarías y Misael (Dn 1-3); Susana (Dn 13); Daniel y los leones (Dn 6). También encontramos el caso de justos que se salvan tras la muerte: Daniel y la resurrección (Dn 7-12); los mártires de 2 Mac (2 Mac 7). De entre los primeros, en la obra de Mauriac podemos situar al abate Calou — protagonista de La farisea-. Salvada esta excepción, lo que generalmente encontramos en la producción del novelista francés no es un justo "recompensado" por Yahweh en esta vida, sino un "monstruo" rescatado por la acción de un mártir. Es la providencia divina que interviene en la vida concreta de las personas por medio de mártiresinmolados. A tal efecto, Mauriac parece ser plenamente consciente de la pertenencia de los cristianos al cuerpo místico de Cristo y, por lo tanto, llamados a la imitación de la cabeza, así como a la solidaridad con el resto del cuerpo (cf. 1 Cor 12,12-27).

En efecto, el cristiano al estar unido a Cristo por el bautismo, o mejor dicho, al estar configurado con Cristo y participar de su ser está, llamado a imitarlo (cf. Rm 6,1-7). Más aún, en el NT"Jesús sigue un principio general sobre la paternidad: cada uno tiene por padre a quien imita y obedece. Así, solo quien actúa como Dios le puede considerar su padre [...] Por eso, la paternidad de Dios está condicionada a que el hombre actúe a imitación de Dios" ${ }^{69}$ Bien es cierto que los cristianos deben su filiación fundamentalmente a la gracia divina ya que"todos los que se bautizan en el Hijo se revisten de Él llegando a ser hijos de Dios por la fe en Cristo Jesús"70 (cf. Gál 3,26-27). Es precisamente este ser hijo en el Hijo lo que posibilita el hecho de poder imitar a Dios en su perfección y llevar así a plenitud la filiación por imitación..$^{71}$

La actitud de entrega personal para la salvación de los hermanos aparece de forma meridianamente clara en la primera carta de san Juan: "En esto hemos conocido el amor de Dios: en que él dio su vida por

\footnotetext{
69 Agustín Giménez, Si el justo es Hijo de Dios, le socorrerá (Sab 2, 18), Estella, Verbo Divino, 2009, 364.

$70 \quad$ Ibid., 366.

71 Cf. Ibid., 365.
} 
nosotros. También nosotros debemos dar nuestra vida por los hermanos" (1 Jn 3,16). A partir de ahí, se puede afirmar que "el NT ha abierto el camino del justo sufriente que deben recorrer también sus discípulos a imitación del Maestro".$^{72}$ De esta forma, todo cristiano está llamado a ofrecer su vida a Dios y, por extensión a sus hermanos, como sacrificio vivo y santo (cf. Rm 12,1-12) sabiendo que los"sufrimientos de ahora no se pueden comparar con la gloria que un día se nos manifestará" (Rm 8,18). En este sentido, cuando el profesor Montoya Villegas comenta a González Faus sostiene que el sufrimiento solo es eficaz en orden a la redención del hombre si es expresión de la solidaridad. ${ }^{73}$ Es decir," el dolor solo adquiere algún valor cuando es la consecuencia que se produce por ser solidario con los demás". ${ }^{74}$

Por otro lado, según la comprensión de Olegario González de Cardedal, Cristo es considerado como el que ha

desvelado y realizado al máximo lo que define Gen 4,9 como lo constituyente de todo hombre: ser responsable del hermano, su guardián y no su señor, existiendo como portador cargado con el destino de él. El otro debe ser comprendido como nuestro real prójimo [...] y, en consecuencia, la relación con él debe ser de proexistencia [...]. Con su muerte por nosotros Cristo ha revelado a un hombre nuevo que no vive del egoísmo ni de la angustia por su propia afirmación o autonomía, sino que desiste de sí, se ocupa del prójimo y, perdiendo su vida, la gana. ${ }^{75}$

A partir de ahí se puede comprender"el hecho de que la acción de un hombre no quede recluida en la unicidad de su persona, sino que puede tener y tiene una innegable incidencia en los demás" ${ }^{76}$ Este extremo ha sido explanado por el propio Ratzinger cuando afirma que "el costado abierto es el símbolo de una nueva imagen del hombre, de un nuevo Adán; es la contraseña de Cristo como el hombre que existe-para-los-demás". ${ }^{77}$

Así las cosas, releyendo los textos que tenemos entre manos François Mauriac parece querer constatar la acción divina por medio de un pequeño número de mártires-inmolados que pondrían cara a la expiación vicaria. Estos, siguiendo el ejemplo del Maestro se entregarían a sí mismos con

\footnotetext{
$72 \quad$ Ibid., 367.

73 Cf. Montoya, Cur Deus Homo?, 112.

74 Ibid.

75 Olegario González de CARDedal, Cristología (Sapientia fidei 24), Madrid, BAC, 2005, 25.

76 Montoya, Cur Deus Homo?, 368.

77 Joseph Ratzinger, La muerte de Cristo. Meditaciones sobre la Semana Santa, Madrid, Encuentro, 2013, 26.
} 
el único fin de generar vida a su alrededor. De esta forma, serían rescatados los antitipos vitales —a los que llama "monstruos" - y que Mauriac pinta con tanta destreza. ${ }^{78}$

\subsubsection{La farisea (1941)}

Como hemos señalado anteriormente, de entre los justos cuyo sufrimiento y entrega por los demás es restituido por Dios en esta vida encontramos al abate Calou. Con su figura Mauriac presenta el tema de la expiación-sufrimiento-redención vicaria. Él con sus virtudes y defectos entrega la vida en rescate por aquellos que lo rodean, incluso por aquellos que le hacen sufrir — como es el caso de Jean de Mirbel_ o que le hacen objetivamente el mal —Brigitte Pian o la condesa de Mirbel. Tras haber sido despojado de todo - incluso de la posibilidad de celebrar los sacramentos - fue restituido y ensalzado con la confianza de una nueva encomienda pastoral que lo colmó de esperanza y de gozo.

Calou había ido a parar a Baluzac, una población que apenas tenía derecho a llamarse pueblo. Con viviendas muy dispersas solo disponía de una venta y de una farmacia como servicios públicos. ${ }^{79}$ Posiblemente el motivo de tal destino fuese un cierto grado de heterodoxia en sus planteamientos religiosos. Sea como fuere, el abate acogía en su casa como educador a ciertos jóvenes especialmente problemáticos. La novela recoge el caso de un joven aristócrata —Jean de Mirbel-, hijo de la condesa del mismo título. Había perdido ya dos cursos cuando su tío y tutor el conde de Mirbel decidió buscar una alternativa educativa para el verano. Es entonces cuando comienza la relación entre el clérigo y el joven montaraz.

El abate tenía fama de emplear novedosos y originales métodos pedagógicos basados en la escucha, la libertad y el diálogo. Con todo, impuso una restricción al joven consistente en no frecuentar la farmacia de Voyod. ${ }^{80}$ Aquel joven no pudo comprender la prohibición, pero el clérigo estaba firmemente persuadido de que allí se cernía la tentación y el mal. Todo se remontaba a algunos años antes cuando el Abate ayudó a una

78 El mismo autor reconoce que el tema principal de algunas de sus grandes obras como son Lo que estaba perdido y Los ángeles negros"se resume en el rescate de la masa criminal por medio de un pequeño número de inmolados". François MaURIac, "Prefacio", en ID., Obras completas, I, 18.

79 Cf. ID., La farisea, 657.

80 Cf. Ibid.; cf. Ibid., 772. Mauriac parece querer hacer un paralelismo entre la prohibición al joven por parte del clérigo de no frecuentar la farmacia y la prohibición de Dios en el jardín del Edén. En ambos casos se incumplió la restricción y las consecuencias perniciosas no se hicieron esperar. 
joven maestra a zafarse de la influencia de Hortense Voyod, mujer del anciano farmacéutico. A partir de ese momento ella, plena de rencor y de odio, fue urdiendo su venganza. ${ }^{81}$

El primer ataque ideado por la farmacéutica fue el recurso a las"pasiones anticlericales muy vivas en aquella época" ${ }^{82} \mathrm{~A}$ tal efecto se sirvió del maestro, así como de su esposa, para establecer una especie de comité de propaganda anticlerical, ${ }^{83}$ pero el efecto fue muy limitado dada la mala reputación de Hortense. Esto, junto con su desinterés hacia los jóvenes y su poco atractivo, hizo que el clérigo se confiase, extremo este que le haría arrepentirse.$^{84}$ Él pensaba que había ido ganando terreno en la relación con el joven Mirbel sin caer en la cuenta de que existía en él una"repulsión instintiva, un disgusto hacia el hombre profesionalmente casto". ${ }^{85}$ Asimismo, había olvidado que "nada se ha conseguido de una vez para siempre en nadie, ni en amor ni en amistad" ${ }^{86} \mathrm{~A}$ ello se le sumaba el hecho de que, por diversos motivos, Jean había sido despojado de los dos centros gravitacionales de su vida: su madre y Michèle, la joven Pian de la que se había enamorado aquel verano en Baluzac.

Por otro lado, el pobre abate, cuando tenía que corregir al joven dada su licenciosidad-, tenía que soportar sus desplantes e incluso su violencia. Todo lo soportaba y justificaba por el bien de su alma:"Se armó contra mí porque soy un padre débil —anotó el abate en su cuaderno [...]. Incluso el alma menos cristiana exige de nosotros que amemos por Dios, por ese Dios en el que esta alma no cree" ${ }^{87}$

Este panorama preparaba un escenario óptimo para la nueva entrada en escena de Hortense Voyod. Esta se dedicó a captar la atención del joven hasta que su influencia se hizo decisiva. Con la fuga de ambos tomó cuerpo la venganza tanto tiempo anhelada. ${ }^{88}$

Tanto la fuga como la defensa del amor entre Jean y Michèle le granjearon al párroco de Baluzac la animadversión de las tres familias implicadas e incluso la crítica de su propia feligresía. Todo ello derivó en cartas de protestas al arzobispo que empezó por retirarlo de la parroquia y terminó por prohibirle celebrar la misma eucaristía. ${ }^{89}$ Por su parte el abate Calou lo iba asumiendo como "la última lección de aquella cruz

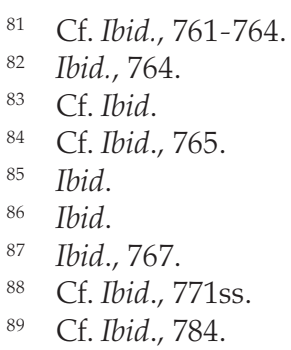


fijada en tierra, inmóvil, y sobre la que se había clavado a un Dios incapaz de moverse. Así el sacerdote, atado al mismo madero, ofrecido a la misma irrisión, propone a los hombres un enigma que ellos no intentan descifrar" ${ }^{\prime 90}$ El clérigo pudo vengarse en numerosas ocasiones, especialmente de la Condesa de Mirbel a quien podría haber aniquilado, pues estaba al corriente de sus mentiras, así como de sus aventuras. Con todo, decidió soportar en silencio los ultrajes. ${ }^{91}$

El párroco se había desvivido por aquel muchacho que ahora lo abandonaba robándole los pocos ahorros que había podido reunir a lo largo de su vida. Pero su conciencia estaba en paz, por eso el narrador se pregunta, “ ¿cómo el sacerdote no hubiese estado tranquilo con respecto a Jean [...] habiendo ofrecido su vida por él renovando casi a diario su sacrificio?"..$^{92}$ A pesar de todo lo que estaba sufriendo, anteponía su ministerio y su misión a cualquier calumnia:

Porque no es la calumnia la que me ha sido escatimada [comenta el abate]; las gentes pueden creer lo que quieran, y lo mismo el arzobispo y quien sea. Puedo decir que, habiendo ya alcanzado los comienzos de la vejez, he perdido todo mi modesto honor humano y he dejado ultrajar en mi persona a ese Jesús que me había marcado con su signo. [...] estoy ahora ante Dios más desnudo que nadie en el mundo. He aquí, tal vez, el estado que deben alcanzar los hombres en quienes la virtud, me atrevo a decirlo, es una profesión. ${ }^{93}$

En cuanto a la Sra. Pian que lo acusaba de participar en intrigas amorosas no solo no deseó su mal, sino que oró y veló por la conversión de su alma. ${ }^{94}$ Él estaba convencido de que Dios tenía una historia de amor para cada una de sus criaturas y nadie debía juzgarla. ${ }^{95}$

Calou desde la llegada del joven Jean a la casa rectoral había comenzado un inexorable ascenso a su propio Calvario cuyo punto de inflexión fue la privación de su ministerio. ${ }^{96}$ Con amargura, pero con humildad y mansedumbre, el antiguo párroco asumió su nueva situación. Asistía a misa "cada mañana, en una capilla cerca de la facultad de Letras, en el momento de la comunión, se mezclaba su sotana con los trajes negros de las viejas.Volvía luego a su puesto bajo las miradas curiosas o compasivas

\footnotetext{
$90 \quad$ Ibid., 772.

91 Cf. Ibid., 783.

92 Ibid., 778.

93 Ibid., 785ss.

94 Cf. Ibid., 786.

95 Cf. Ibid., 792.

96 Cf. Ibid., 799. 806.
} 
de la gente, y su rostro era el de un ángel" ${ }^{97}$ Finalmente, fiel a la convicción cristiana de que quien muere en el Señor, resucita con él (Col 2,20; 3,1-3), el abate, ayudado por la convertida Bigitte Pian, fue restituido recobrando el favor de la autoridad diocesana — que no el de Dio — s el cual nunca había perdido. ${ }^{98}$

\subsubsection{Thérèse Desqueyroux (1927)}

En cuanto a los monstruos que Mauriac quiere rescatar por la intervención de mártires-inmolados encontramos un primer ejemplo en la vida de Thérèse, protagonista de la obra que lleva por título su mismo nombre. En ella la gracia divina actúa por medio de una tía solterona, sorda y obesa. Ella era todo bondad, con esmero no solo cuidaba de las tareas domésticas, sino que atendía a los menesterosos colonos a quienes nadie prestaba la más mínima atención. ${ }^{99}$ La anciana procuraba facilitar la vida de Thérèse, así como la del resto de la familia. Además, asumía con resignación la incomodidad que generaba su mera presencia. Con todo, aquella"emparedada viva"100 fue un instrumento clave en manos de Dios. Más aún, en pleno desarrollo del drama cuando Thérèse estaba preparando la pócima mortuoria para sí misma le suplicaba e incluso le exigía a Dios que abandonase su silencio e interviniese: "Si existiese ese Ser [...]; puesto que Él existe, que desvíe la mano criminal antes de que sea demasiado tarde; y si es su voluntad que una pobre alma ciega franquee el pasaje, que pueda, al menos, acoger con amor a este monstruo". ${ }^{101}$

Cuando Dios parecía mudo y Thérèse se encontraba en el más profundo de los abandonos, el Ser al que se dirigían sus súplicas rompió el alba impidiendo la tragedia: "Balionte entra sin llamar: — ¡La señorita está muerta!". ${ }^{102}$ A partir de ese momento Thérèse se va a ir liberando progresivamente de las ataduras que la atenazan descubriendo el germen de la espiritualidad y a ese Ser Infinito que no permanece en el silencio. Esto mismo lo explana aún más el novelista francés en El fin de la noche donde Thérèse descubre la misión espiritual a la que ha sido llamada: "entrar profundamente en los corazones medio muertos, para

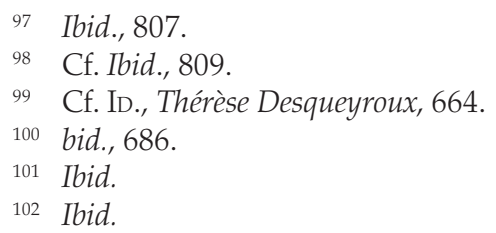


conmoverlos" ${ }^{103}$ La espiritualidad es en este caso la rendija por la que el poder de la gracia actúa con el fin de rescatar al monstruo.

\subsubsection{Lo que estaba perdido (1930)}

En otra de las grandes obras del premio Nobel — Lo que estaba perdidolas víctimas inmoladas son Irene, Marie Chaves y, en cierto sentido, la madre de Hervé. Como consecuencia de sus vidas, sus acciones e incluso sus muertes los monstruos irán siendo rescatados de la vida ruin y encaminados hacia la senda redentora.

Por un lado, encontramos la pareja formada por Hervé Blenauge e Irene que llevan seis años de matrimonio. Ella "sufría como el primer día"104 porque "no la había amado nunca, ni un solo instante, jamás". ${ }^{105}$ Ella le amaba, pero él todo lo hizo por su dinero. ${ }^{106}$ Incluso la madre de Hervé que sentía pasión por su retoño era consciente de sus debilidades. ${ }^{107}$ Irene podía ser considerada como una persona buena en el sentido estricto de la palabra. Era caritativa, paciente hasta el extremo, comprensiva y austera hasta el punto de llegar a ser considerada como la "Musa austera". ${ }^{108}$

Irene intentó por todos los medios cambiar el rumbo de la vida de su marido aplicando dosis incesantes de amor. Por eso se llega a reprochar:"creía que se puede vivir amando sin ser amado; y que el amor, con paciencia, acaba por reformar y modelar según sus ideas al ser en el cual se complace. Pasaba por alto todas las mentiras de Hervé, y se esforzaba en enderezarle sin encolerizarse" ${ }^{109}$ Finalmente, vencida por el dolor infringido por Hervé, así como por la enfermedad ella misma anticipa su muerte ante lo cual Mauriac concluye: "es preciso que atraviese hasta el final las tinieblas en las que tan insensatamente se arrojó. Pero,

103 ID., El fin de la noche, 906.

104 ID., Lo que estaba perdido, 941.

105 Ibid., 1009.“"Nada de lo referente a ella tenía la virtud de interesarle": Ibid., 971."Hervé andaba de prisa, experimentando en cada paso la delicia de alejarse de la casa y de Irene": Ibid., 971.

106 Cf. Ibid., 1011.

107 Cf. Ibid., 973.

108 Ibid., 995; cf. Ibid, 971. Según Marcel —amigo común de la pareja—, Irene "tenía todas las virtudes que se atribuyen a los hombres [...] Era discreta hasta el extremo de olvidar las confidencias que recibía. Era el único ser que él conocía, en el cual la atención iba unida a un visible deseo de ayudar [...] Irene [...] quiere socorrer, hacer el bien: es como una vocación. Sufre, y uno se olvida de compadecerla. Con toda naturalidad uno cuenta sus miserias a aquella desgraciada": Ibid., 993. Ibid., 1011. 
deslizándose en el abismo conocía, veía y llamaba al fin, por su nombre, a aquel amor que está por encima de todos los hombres" ${ }^{110}$ La recompensa de su entrega, amor y sufrimiento no se encontraba en este mundo, sino en el otro (cf. Dn 7-12: cf. 2 Mac 7). Por eso abría los brazos de par en par para abrazar a su Creador. En efecto, los ultrajados y despreciados en este mundo por causa de Cristo y de su evangelio del amor (cf. Mt 5,10-12; 1 Pe 2,19; 3,14; 4,13) recibirán una gran recompensa (Mt 5,12; Lc 6,23) y una herencia incorruptible (1 Pe 1,4). Poseerán el reino de los cielos $(\mathrm{Mt} 5,10)$ y por haber muerto con Cristo reinarán con Él (2 Tim 2,11ss.). ${ }^{111}$ A Irene se le puede considerar como uno de los "tipos" de persona que Mauriac va delineando en sus novelas por medio de los cuales va operando la providencia divina.

Hervé por su parte, parece no tener ningún aprecio por su mujer y busca la menor excusa para alejarse de su lado y abandonarla en su desvalimiento. Cuando Hervé se dejaba atrapar por el vicio la puerta se cerraba y su débil voluntad era incapaz de abrirla, algo de lo que era plenamente consciente. En este caso, Hervé es utilizado por Mauriac como "antitipo" de la virtud para el que lo único que contaba era lo que le daba placer. ${ }^{112}$ A menudo se debatía entre lo correcto y lo incorrecto, y eso le hacía ser consciente de que, sucediera lo que sucediera, estaría a la vez contento y desolado. ${ }^{113}$ En esa tesitura siempre cedía a sus inclinaciones más bajas. Mauriac dibuja a Hervé como la síntesis de los pecados y la degradación, incluso llegando a insinuar su homosexualidad. ${ }^{114}$ Tras la muerte de Irene, Hervé intenta justificar su comportamiento, ${ }^{115}$ pero la culpa lo acorrala. Por eso llega a afirmar de sí mismo: "soy horrible". A pesar de todo, Hervé se siente juzgado como lo había sido por Irene durante su vida: con perdón y misericordia. ${ }^{116}$

Ahora bien, incluso en el pecador más atroz se puede atisbar la esperanza de la acción de la gracia y de la conversión. Eso ocurre en el caso de Hervé tanto por los ruegos y desvelos de su mujer como por los de su madre. En especial este extremo queda puesto de manifiesto en el lecho de muerte de la progenitora cuando el amor y la veneración que no profesó a su esposa emergen con naturalidad.Y es que cuando"entraba en la habitación de su madre cambiaba de mirada y de voz: cambiaba el

\footnotetext{
110 Ibid., 1014.

111 Giménez, Si el justo es Hijo de Dios, le socorrerá (Sab 2, 18), 369.

112 Cf. Mauriac, Lo que estaba perdido, 972; cf. Ibid., 974.

113 Cf. Ibid., 1008.

114 Ibid., 1011.

115 Cf. Ibid., 1019ss.

116 Ibid., 1020.
} 
alma. Para penetrar en aquel reino se volvía niño [y, por tanto, inocente y puro]". ${ }^{117}$ De hecho, "Tota [—una amiga—] se sintió conmovida por la apasionada atención que él consagraba a su madre enferma". ${ }^{118}$

\subsubsection{Nudo de víboras (1932)}

En Nudo de víboras Mauriac vuelve a sumergirse en el misterio del mal profundizando en los efectos del mismo en el corazón de sus monstruos. Nuevamente perfila a sus víctimas-mártires encargadas del rescate de sus infelices. En este caso los personajes destinados a tal fin son Isa, la mujer de Luis —el protagonista-, la hija difunta en su niñez — María- y el sobrino, hijo de Marinette - Lucas-, difunto en su juventud. Ellos son las verdaderas víctimas por las que Dios actúa en la historia de Luis. Su vida y, sobre todo, su muerte son los acicates que van jalonando la conversión del antiguo monstruo. Las herramientas son el amor, el perdón, el cariño, la perseverancia, la espontaneidad o el desprendimiento, entre otros. Todo ello irá calando en el viejo huraño hasta que su corazón se enterneció de tal manera que se pudo deshacer el nudo de víboras que lo atenazaba.

En el caso de Isa, su amor de juventud provocó la chispa que iluminó una primera conversión que, aunque efímera, fue significativa en la vida de aquel joven oscuro, tímido y odioso para cuantos compartían la existencia con él. ${ }^{119}$ En ese momento experimentó "la viva sensación, la certidumbre casi física, de que existía otro mundo, una realidad de la cual no conocíamos más que la sombra".${ }^{120}$ Dios le había tocado en el corazón por medio de Isa y lo había abierto hacia la trascendencia.

Con todo, el nudo de víboras que habitaba en su corazón era muy poderoso en el joven Luis. De ahí que los celos, así como la desconfianza, hicieron que se revertiera aquel incipiente proceso. Su matrimonio duró cuarenta años; fueron años de amargura, sufrimiento y distanciamiento entre los esposos. ${ }^{121}$ Solo al final, después de ese desierto lleno de angustias, fue cuando tras la muerte de su esposa su corazón se ablandó desapareciendo por completo el odio, el rencor, así como el ansia de venganza. ${ }^{122}$ Muy probablemente Mauriac fijase en cuarenta los años de matrimonio en analogía a los cuarenta años de Israel en el desierto, años

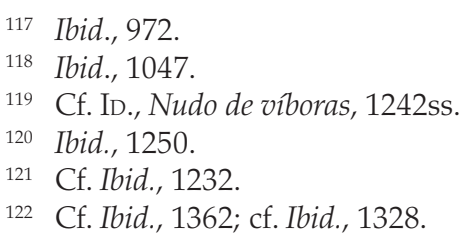


de peregrinación, purificación y descubrimiento del verdadero rostro del Señor. Curiosamente como Moisés, tampoco Isa alcanzó a pisar la tierra prometida de la conversión de Luis, después de una infinidad de sacrificios y oraciones. Ella, al igual que Moisés, también había intentado conducir a su esposo en el seguimiento del Dios único y verdadero por el desierto de su vida. Probablemente el novelista francés podría haber terminado la confesión de Luis con las palabras de Job: “Te conocía solo de oídas, pero ahora te han visto mis ojos" (Job 42,5). Ahora Luis también admitía el conocimiento limitado de Dios por medio de testigos muy imperfectos, y solo el encuentro con Él en la experiencia del amor le dio el verdadero tono de su Creador. Isa durante toda su existencia se dedicó al cuidado familiar con especial esmero de su marido pese a sus impertinencias, desplantes o intrigas. De esa forma también le fue mostrando el rostro paciente de Dios. ${ }^{123}$

Otro fogonazo de luz trascendental fue el protagonizado por María, la menor del matrimonio. Ella era la única que entre los vástagos del matrimonio no le tenía miedo al progenitor. Más todavía, disfrutaba con su compañía. Todo ello, junto a su pureza y su bondad, interpelaba constantemente al padre:

[María] Era la única que no me irritaba. Cuando sus dos hermanos mayores adoptaron ya las creencias que tú practicabas, con ese instinto burgués de comodidad que los haría prescindir más tarde de todas las virtudes heroicas, de toda la sublime locura cristiana, en María, por el contrario, había un fervor conmovedor, una ternura espiritual por los criados, por los aparceros y por los pobres. Se decía de ella: [...] A todos acepta su bondad, incluso a su padre. ${ }^{124}$

Su vida, pero sobre todo su muerte dejó una profunda huella en el corazón atormentado de Luis. La madre había inculcado en sus hijos la necesidad de rezar por la conversión del" pobre papá" ${ }^{125}$ Quizás por ello en el lecho de muerte cuando la niña tomaba conciencia de su situación solo alcanzaba a susurrar:“¡Por papá!...jPor papá!..."126 Con el transcurrir de los años se comprobó cómo el sufrimiento intercesor de la pequeña fue escuchado por el Creador. Este no limitó su acción en la vida del viejo huraño al periplo terreno de la pequeña, sino que tras su muerte se siguió sirviendo de ella para abrir el horizonte de este a la trascendencia. De hecho, llega a recoger con plena conciencia que"al cabo de los años,

\footnotetext{
123 Cf. Ibid., 1301ss.

124 Ibid., 1281.

125 Ibid., 1280ss.

126 Ibid., 1298; cf. Ibid., 1385.
} 
yo sentía vivir a mi hija y la respiraba, y que atravesaba frecuentemente mi vida tenebrosa con un brusco soplo". ${ }^{127}$

Otro aldabonazo por parte de la gracia divina en el corazón del Luis maduro se realizó por medio del joven Lucas, huérfano de Marinette, la hermana de Isa: "En aquella época nuestros hijos [...] se habían puesto definitivamente a tu lado y vueltos contra mí en toda ocasión [...] me sostenía el odio, pero también el amor, el amor que sentía por el pequeño Lucas". ${ }^{128}$ Él, pleno de alegría así como de vitalidad natural, le demostraba espontáneamente su cariño y su valor en medio de una familia que si le mostraba algo era indiferencia: ${ }^{129}$ "Aquel muchacho era el único ser en el mundo para quien yo no era un espantajo. [...] Lo que más me asombraba [...] era su pureza, su ignorancia del mal".${ }^{130}$ Tal fue el binomio amorodio que inundaba su corazón que había decidido poner todo su caudal a nombre del chiquillo. ${ }^{131}$ Incluso intentó darle un cinturón repleto de monedas de oro. ${ }^{132}$ Tanto una cosa como la otra fueron rechazadas por aquella alma pura. Todo ello fue lo que le proporcionó la medida del mal:

La pureza, en él, no parecía adquirida ni consciente: era la limpidez del agua entre las piedras. Brillaba sobre él como el rocío sobre la hierba. Si me detengo en ella es porque repercutió en mí de una manera profunda. La ostentación de tus principios, tus alusiones, tus actitudes de disgusto, tus labios fruncidos, no hubiesen podido darme el sentido del mal que me dio, sin saberlo, aquel niño. Me di cuenta mucho tiempo después. Si la humanidad tiene una herida original en el costado, como tú supones, ninguna pupila humana la hubiese visto en Lucas. Había salido puramente intacto de manos del alfarero, poseído de una perfecta gracia. Y yo, yo sentía a su lado mi deformidad. ¿Puedo confesar que le he querido como a un hijo? No, porque lo que yo en él amaba era no encontrarme en él. ${ }^{133}$

Lucas era piadoso incluso portaba siempre en su bolsillo un pequeño rosario, ${ }^{134}$ pero su cristianismo puro no espantaba a quien no pensaba como él, sino que más bien le interpelaba. ${ }^{135}$ Fue el conjunto de todo

\footnotetext{
127 Ibid., 1331.

128 Ibid., 1301.

129 Cf. Ibid., 1304ss.

130 Ibid., 1305.

131 Ibid., 1300.

132 Cf. Ibid., 1308.

133 Ibid., 1305ss.

134 Cf. Ibid., 1306.

135 “Los domingos por la mañana parecía tal vez más tranquilo que los demás días, menos ligero, menos imponderable y como saturado de una sustancia desconocida": Ibid., 1306.
} 
ello revivido con intensidad por Luis en el tramo final de su vida, lo que dirigió su conciencia a descubrir el intenso amor que le abrasaba el corazón y cuyo nombre al fin conocía: ${ }^{136}$ "Incansablemente, [había] deseado perder esa llave [María, Lucas e Isa] que una mano misteriosa me [había] ofrecido siempre a cada vuelta de mi vida". ${ }^{137}$

Asimismo, fue plenamente consciente de la fealdad de su corazón: "Conozco mi corazón, este corazón, este nudo de víboras. Ahogado por ellas, saturado de su veneno, continúa latiendo por encima de ese hervidero. Nudo de víboras imposible de desanudar, que será necesario romper de un navajazo, de una cuchillada: Yo no he venido a traer la paz, sino la guerra (Mt 10, 34)". ${ }^{138}$ Pero no solo eso, al final de sus días constató ese halo de bondad que hacía sonar Dios por medio de sus pequeños mártires:"Tú ves, sin embargo, que existe en mí una fibra secreta, aquella que hacía vibrar María con solo acurrucarse en mis brazos, y también el pequeño Lucas, los domingos, cuando de regreso de misa, se sentaba en el banco que hay frente a la casa y contemplaba la pradera" ${ }^{139}$ Todo ello va conmoviendo sus firmes convicciones anteriores para abrirse al arrepentimiento comenzando por la súplica del perdón de su esposa. ${ }^{140}$

Pero esta noche [dice Luis] me he vuelto un extraño para lo que era mi bien, en amplio sentido de la palabra. En fin, carezco de interés por las cosas. No sé qué, no sé qué me ha despegado, Isa; se han roto las amarras; voy a la deriva. ¿Qué fuerza me arrastra? ¿Es una fuerza ciega? ¿Un amor? Puede que un amor... ${ }^{141}$

En el atardecer de su vida llegaba a la conclusión de que su gran crimen no consistía en su particular nudo de víboras, en el

odio de mis hijos, deseo de venganza y amor al dinero, sino en mi negativa de buscar más allá de aquellas víboras entrelazadas. Había estado aferrado a aquel nudo inmundo, como si hubiese sido mi propio corazón, como si los latidos de este corazón se hubiesen confundido con aquellos reptiles hormigueantes. No había bastado, a lo largo de medio siglo, no conocer en mí nada más que lo que yo era. Incluso había usado de ello contra los demás. ${ }^{142}$

Finalmente tomaba conciencia de que durante toda su vida había buscado a Dios; de que la esperanza siempre deja en nosotros una

\footnotetext{
136 Cf. Ibid., 1385.

137 Ibid., 1385.

138 Ibid., 1311.

139 Ibid., 1311.

140 Cf. Ibid., 1311ss.

141 Ibid., 1313.

142 Ibid., 1371.
} 
semilla. ${ }^{143}$ Así pues, desatado ese "nudo de víboras", desasido de todo interés por lo material y tras haber entregado todos sus bienes a su descendencia $^{144}$ terminó por encontrarse con el Amor que lo había perseguido durante toda su vida y a él se entregaba. Todo ello llenaba su corazón de paz como nunca antes lo había tenido. ${ }^{145}$ Una paz que procedía de aquel que lo había encontrado. ${ }^{146}$ Ese cambio vital experimentado por Luis le llevó a empezar a juzgar a su familia como nunca antes lo había hecho. Lejos de sus víboras intentaba conocer y amar el corazón de los suyos. ${ }^{147}$ Con ello Mauriac profundizaba en la idea de la acción de la providencia divina por medio de personas concretas cuyo martirio en vida posibilita la conversión del pecador deshaciendo el "nudo de víboras" que atenaza su corazón.

\subsection{5. Ángeles negros (1936)}

En el caso de los Ángeles negros las víctimas son Adila, y, cómo no, Alain Forcas. Por medio de ellos será rescatado en primer lugar otro de los "antitipos" de la virtud que perfila Mauriac, Gabrile Gradère. Más aún, las víctimas serán la oportunidad de conversión del resto de personajes como el viejo Sinforiano Debats —un avaro y muñidor empedernido- o Matilde, enamorada de su hijo de adopción, Andrés. Este mismo también será reconducido por el joven sacerdote para que abandone la idea de ir tras su hermana Tota. Catalina, la hija infeliz de los Desbats, calculadora y estratega como su padre, se convierte a su vez en víctima del amor no correspondido por Andrés. Ella, que lo tenía todo previsto, estará dispuesta al sufrimiento siempre y cuando retenga entre sus brazos al primo adoptado.

Acerca de Alain Forcas el propio autor asegura que"escogido, llamado de en medio de este mundo perdido, sufre y paga por todos mis miserables héroes" ${ }^{\prime 148}$ al estar dispuesto a seguir la llamada de Dios. ${ }^{149}$ Mauriac completa en Los ángeles negros la caracterización del joven sacerdote. Si

\footnotetext{
143 Cf. Ibid., 1352.

144 Cf. Ibid., 1365ss.

145 Cf. Ibid., 1371; cf. Ibid., 1381.

146 Cf. Ibid., 1381.

147 Un ejemplo lo constituye Phili el marido de Janine. Antes había sido directamente odiado y ahora intentaba comprender las motivaciones profundas de su actuar. Cf. Ibid., 1377ss. Asimismo, encontramos en Luis ternura, piedad y compasión por su nieta a la que antes había despreciado. Cf. Ibid., 1383ss.

148 François Mauriac, "Prefacio", en ID., Obras completas, I, 17.

149 El corresponder a la llamada divina es, según el novelista francés, el único mérito que el hombre puede tener ante Dios en esta vida. ID., Los ángeles negros, 1207.
} 
en el tramo final de Lo que estaba perdido se estableció su salida de la vía de la perdición gracias a la llamada divina al sacerdocio, ahora quiere disponer un cierto paralelismo entre él y Jesucristo.

Comienza por caracterizarlo como a un siervo sobre el que recaen las burlas por la ayuda que dispensa a los demás. Un ejemplo claro es el de la hojarasca tirada en su puerta como clara insinuación de un posible amancebamiento, ya que solo se hacía esto en la noche de nupcias. Ante ello el sacerdote se planteó si no era su deber atajar de una vez para siempre el escándalo, así como las habladurías. Todavía estaba meditando en ello cuando en lo más profundo de su interior surgió una voz que decía: "Yo no temí el escándalo, aunque estuve desnudo, atado desnudo a una columna, y fui crucificado desnudo... No tienes que comprenderme, sino imitarme...". ${ }^{150}$ Todo ello lo perfila mejor el propio Gabriel Gradère:

Es la irrisión del pueblo. El ridículo y la vergüenza le anonadan. Es un cobarde: le afrentan a escupitajos y se calla. Le llevarían al matadero y ni siquiera balaría. Los demás le imputan todos los actos pecaminosos que realizan y él consiente en asumirlos. Resiste al ansia de gritar que no ha sido él, es un miserable despojo humano, un sufrelotodo del que todo el mundo se mofa sin que él encuentre nada que contestar. Está solo en su iglesia, murmurando oremus..., y, como tú misma haces, sus buenos feligreses le huyen y le desprecian..." ${ }^{\prime 151}$

Estamos ante un mártir que sufre en silencio por los pecados de sus feligreses; un pastor que ora con amor por todos ellos. ${ }^{152}$ Todo lo hace sin protestar, en silencio, aceptando el escarnio y la burla. ${ }^{153}$ De esta forma Mauriac parece querer establecer un paralelismo entre Alain Forcas y el Cristo de la primera carta de Pedro. Más aún, el joven sacerdote manifiesta su amor incondicional hacia sus ovejas y el desprendimiento de todo cuando decide acoger en su propia casa al mancillado Gradére. No le importan las consecuencias de su acción sino lavar y curar las heridas de un alma atormentada como si del Buen Samaritano se tratase. ${ }^{154}$

Por su parte, Alain reconoce el cariño que siente por su hermana Tota y acepta el martirio y el escarnio público por ella. ${ }^{155}$ En este sentido reconoce tanto su debilidad como su confianza y, por tanto, su fortaleza en aquel que todo lo puede:

\footnotetext{
150 Ibid., 1107.

151 Ibid., 1180.

152 Cf. Ibid., 1165.

153 Cf. Ibid., 1096.

154 Cf. Ibid., 1206.

155 Cf. Ibid., 1153.
} 
Tensóse [Alain] en un esfuerzo violento para ahogar, apenas nacido, su criminal deseo de ser un copo más entre aquellos copos [un pecador entre pecadores], la tentación que le horrorizaba de no apartarse del gran número de los condenados. Logró producir el vacío en sí mismo y estuvo suspenso. Diáfana le llegaba desde el fondo de los tiempos la respuesta de Cristo al apóstol que le preguntó: -Así, pues, Señor, ¿nadie será salvo?

-Nada es posible al hombre; todo es posible a Dios. Todo es posible para el amor; el amor desbarata la lógica de los doctores. ${ }^{156}$

A este Dios que lo escucha le confiaba las almas de los pecadores por las cuales llegaba a "llorar de amor". ${ }^{157}$ Nuevamente se constata cómo Mauriac tiene interés en hacer emerger la idea de que incluso el más puro de los seres creados no está exento de la tentación y de los sentimientos más reprobables como el odio. En su pedagogía Mauriac quiere asentar el hecho de que solo mediante la combinación del amor a Dios, la fe, la gracia y una voluntad férrea se pueden superar las asechanzas del mal. ${ }^{158}$ Una fe que le hace confiar en su Creador que hacía resonar su voz en lo más profundo de sus entrañas:"Estoy aquí no temas; estoy aquí para toda la eternidad". ${ }^{159}$

En esta misma obra, aparece la imagen de Adile Du Buch, una joven burguesa que había cedido a la tentación del joven ángel negro Gabriel Gradére. Extremo este que pagaría con el martirio y la propia muerte. Adile era plenamente consciente de que al contraer matrimonio con él se precipitaba por un camino escarpado y sin retorno, un camino de martirio, negación de sí y sacrificio continuado. Ahora bien, un camino en el que no se encontraba sola, pues su fe le aseguraba la ayuda divina. ${ }^{160}$ En ella se puede decir que se da la redención por sufrimiento y el rescate del pecador por martirio. ${ }^{161}$ Adile, pecadora en su juventud, entregó toda su vida al martirio en vida de un matrimonio basado en un amor no correspondido. De esta forma expió sus pecados y provocó que las entrañas profundas de Gabriel se removiesen hasta reconocer: “¿Me creerá usted si le digo que la he llorado, que pienso en ella como en un ser vivo, como

\footnotetext{
156 Ibid., 1164.

157 Ibid., 1165.

158 Ibid., 1217ss.

159 Ibid., 1218.

160 Cf. Ibid., 1075.

161 Gradére reconoció que en lecho de muerte Adila "únicamente pensaba en mí; ni siquiera pronunció el nombre de su hijo... Confiese usted que es una chocante creencia la de la redención por el sufrimiento, la del sacrificio de una vida que no depende de nosotros...": Ibid., 1085.
} 
si no hubiera abandonado la vida?". ${ }^{162}$ Estamos ante la conversión del pecador más atroz cimentada en el amor y la entrega de su esposa.

\subsubsection{El Cordero (1954)}

Desde el mismo título de la novela parece claro que una de las principales intenciones de Mauriac es ir consolidando su convicción personal de la necesaria expiación vicaria del cristiano en el mundo. Para ello intenta trazar un paralelismo entre Jesucristo, que entrega su vida por todos, $y$ el joven Xavier Dartigelongue que trata de rescatar a todos aquellos que el Señor pone en su camino: "No era él quien existía, sino los seres hacia los cuales se sentía perpetuamente como impulsado, para darles vida". ${ }^{163}$ Esta determinación llegará hasta el extremo de estar dispuesto a sacrificar la propia vida por la de sus hermanos. Ahora bien, ¿cuál era la fuente y el origen de esa voluntad expiatoria? En este sentido se pregunta el narrador:

¿De dónde le venía ese amor desproporcionado, ese amor absurdo? No los conocía, nunca los volvería a ver.Y, sin embargo, habría querido llamarlos por el nombre de pila, retenerlos, entrar en la vida de cada uno de ellos, protegerlos de todo peligro, protegerlos con su propio cuerpo. ¡Pasión monstruosa, pasión divina, sí! ¡Era eso! Pasión de Dios por su criatura. ${ }^{164}$

En efecto, era el amor de Dios el que lo arrastraba a amar hasta el extremo a los seres que lo rodeaban.

Xavier era un veinteañero muy asido de la providencia divina. Con todo, era consciente de que lo dominaba "la tentación de los demás"; 165 el interés invencible por las personas que encontraba a su paso. Esto, que para su director espiritual no era sino deleite en las cosas del mundo, podría llegar el momento en que, como un extraordinario don sobrenatural, sirviera para las conquistas de la gracia divina. ${ }^{166}$ Sea como fuere, Xavier era arrastrado inexorablemente a intentar salvar a cuantos se cruzaban en su camino. Él se diferenciaba de ellos"por su corazón insaciable y por esa hambre de querer, de sufrir y de morir que no había encontrado en ninguna otra criatura". ${ }^{167}$ Su afán era"ser todo entero de todos y de cada

\footnotetext{
162 Ibid.

163 ID., "El Cordero", en François MaURIAC, Obras selectas de premios Nobel: François Mauriac 1952, Barcelona, Planeta, 1987, 651.

164 Ibid. Las cursivas son nuestras.

165 Ibid., 635.

166 Cf. Ibid.

167 Ibid., 651.
} 
uno". ${ }^{168}$ Más aún, el rostro de la amargura, el dolor, la angustia o la vulnerabilidad de los seres que lo rodeaban repercutía en un sentimiento de profundo sufrimiento difícil de perfilar. Eran los débiles y los indefensos que el Señor situaba a su vera los que ponían rostro a este sufrimiento. ${ }^{169}$ Así las cosas, en cuanto se percataba de un ser necesitado lo abandonaba todo y se centraba en él sin reservarse nada.

El escenario dibujado por Mauriac había llevado al joven a decidirse por el seguimiento radical del Señor como sacerdote de la Nueva Alianza. Su entrada en el seminario habría sido una realidad si un alma descarriada y perturbada como la de Jean de Mirbel no se hubiese cruzado en su camino en el tren que lo llevaba hasta Burdeos. Fue tanto la amargura como la infelicidad con la que había quedado su abandonada esposa Michèle Pian - las que dilataron su ingreso en la institución eclesiástica. Posteriormente se cruzaron otras dos almas en su camino: por un lado, Roland —el niño adoptado y repudiado al poco por los Mirbel—; por otro, el cura de Baluzac — un sacerdote que había perdido la fe-. El propio Xavier le dice"he venido para ayudarlo a llevar su cruz... o quizá para llevarla en su lugar" ${ }^{170}$ Todo ello, hizo que se resignase a permanecer "prisionero" en la casa de los Mirbel hasta que llegó el fatídico accidente que terminó con su vida.

Con todo ello el autor pretende transmitir a sus lectores la importancia de la responsabilidad del cristiano respecto de los que lo rodean. Dicho de otra forma, quiere dejar sentada su convicción de que al final de los tiempos, cuando estemos ante el tribunal divino, se nos preguntará sin ambages: “qué has hecho de tu hermano?". ${ }^{171}$ Cuestión que se nos repetirá "tantas veces como en el curso de nuestra existencia hayamos reinado sobre alguien, hayamos tenido poder sobre un corazón, sobre un cuerpo, hayamos usado o abusado de ese cuerpo...". ${ }^{172}$

Hay un momento de especial relevancia en el paralelismo que intenta trazar Mauriac entre Xavier y Cristo cuando presenta a un preocupado joven que se desplaza hasta la vega casi descalzo en busca de una escalera con la que rescatar al joven Roland. El pequeño huérfano, como castigo, había sido recluido bajo llave en la biblioteca donde habría de dormir sin protección alguna. La determinación de Xavier por asistir al niño conllevará su paso firme, aunque angustioso, en el recorrido de su via crucis particular. A tal efecto dice el narrador:

\footnotetext{
168 Ibid., 657.

169 Cf. Ibid., 661ss.

170 Ibid., 727.

171 Ibid., 728.

172 Ibid.
} 
Esa cruz de la cual hablaba sin cesar, con la cual creía hasta ese día haber alimentado su meditación... Pero que descubría de golpe [...] realmente [en] un madero que aplastaba el hombro herido, y esa piedra y esa tierra, en ese momento, le destrozaban la piel y los pies. Avanzaba en una tensión atroz y creía ver moverse ante él una espalda esquelética; discernía las vértebras, las costillas levantadas por un jadeo precipitado, y el surco violeta de viejas flagelaciones: el esclavo de todos los tiempos, el esclavo eterno. ${ }^{173}$

Xavier callaba ante las ofensas, ${ }^{174}$, caminaba con los pies descalzos para rescatar al oprimido, cargaba con un madero, sufría, quería salvar a su hermano... Ahora bien, su corazón tras la zozobra inicial se llenaba de paz ante el sacrificio. ${ }^{175}$ Mauriac con la figura de Xavier se esfuerza en seguir perfilando el rostro del cristiano que vive su vida como un acto de continua expiación vicaria al estilo de Jesús.

Todo ello entronca con el espíritu mauriaciano según el cual Dios actúa en el mundo de muchas y variadas formas. Entre ellas destaca la del grupo de sus elegidos por medio de los cuales interviene en la vida del resto. En este caso el instrumento divino toma cuerpo en Xavier el cual"creía en un pequeño número de elegidos, pero cada elegido tenía el poder de arrastrar tras de sí a todas las almas, en apariencia condenadas, que le eran adjudicadas". ${ }^{176}$ Esto es a lo que, al más puro estilo hegeliano, Mauriac denominaba astucia de la gracia. ${ }^{177}$

A partir de ahí se puede comprobar cómo nuevamente emerge la creencia de que en el pecador más atroz subsiste una llama de esperanza que la gracia puede avivar por cualquier rendija que se le deje."Nadie es completamente malo"178 respondía Xavier al joven Rolan hablando de los hijos de Jacob; nadie está totalmente perdido. En ese caso el instrumento para rescatar al pueblo de Israel habría sido José un elegido-sacrificado. Por su parte, Xavier será otro de los elegidos-sacrificados para llevar la paz al matrimonio de los Mirbel, el ánimo a Roland, así como el consuelo al cura de Baluzac. Todo ello no abolía el sufrimiento de estos, pero sí permitía su integración y le otorgaba sentido. ${ }^{179}$

\footnotetext{
173 Ibid., 705.

174 Cf. Ibid., 698.

175 Cf. Ibid., 730.

176 Ibid., 645.

177 Cf. Ibid.

178 Ibid., 677.

179 Cf. Ibid., 700ss.
} 


\section{CRÍTICA A LA RELIGIÓN}

François Mauriac se considera como "hijo de la Casa"180 con derecho a irritarse por las desviaciones que en la Iglesia se observan. Con todo, afirma sin ambages su fidelidad a la misma, así como el indefectible amor que le inspira la Iglesia santa. ${ }^{181}$ En efecto,"la Iglesia es santa pero sus miembros son pecadores" ${ }^{182}$ A partir de este axioma, el apologeta francés realiza una audaz crítica a los cristianos desde diversos ámbitos: por un lado, a los clérigos que abusan de la Palabra de Dios; ${ }^{183}$ por otro, cuestiona lo que se pueden llamar desviaciones de la verdadera adoración en espíritu y en verdad. ${ }^{184}$ En el fondo de todo ello late una denuncia a la tibieza de muchos cristianos y a la complacencia de otros con todo lo mundano que distorsiona la radicalidad evangélica. ${ }^{185}$ Asimismo, Mauriac quiere hacer emerger en su crítica la asimilación del cristianismo al mundo. ${ }^{186}$ En este sentido Mauriac critica al materialismo que se ha extendido en la Iglesia. Frente a él no ve otra salida que la santidad de sus miembros:

En la medida que es un poder de este mundo la Iglesia enfrenta, con dificultad, el materialismo virulento que, bajo su forma marxista, le disputa el imperio de los espíritus. Desde el único punto de vista humano su verdadera fuerza reside en la santidad de sus miembros. Los santos constituyen su fuerza [...]. Se puede decir de la santidad que es la cosa del mundo mejor compartida, que penetra en destinos muy comunes en los que solo se manifiesta por la aceptación del deber cotidiano y de la cotidiana prueba: santidad que se ignora a sí misma profundamente, "pequeño camino" con el cual santa Teresa del Niño Jesús constituyó su doctrina y que muchas almas siguen sin conocer su nombre. ${ }^{187}$

Por nuestra parte nos vamos a centrar en el testimonio cristiano, así como en el fariseísmo religioso.

\footnotetext{
180 MaURiac, La piedra del escándalo, 94.

181 Cf. Ibid., 97.

182 Ibid., 92.

183 "He criticado, equivocado o no, lo que me parecieron en ciertos predicadores ser exageraciones, desviaciones y, en ciertos clérigos, un exceso de complacencia frente a bajas formas de devoción, pero se trataba, en mi espíritu, de errores en relación a la verdad que siempre ha enseñado la inmutable Iglesia»: Ibid. "Los sacerdotes y los religiosos que se entregan al ministerio de la palabra tan torcidamente que sus consecuencias nefastas escapan a todo control....": Ibid., 34. "No existe pequeña mentira para quien habla en nombre de Dios. Uno no se sirve de la Palabra de Dios, uno no la utiliza. La utilización: he aquí el vicio de ciertos clérigos": Ibid., 40ss.

184 Cf. Ibid., 41ss.

185 Cf. Ibid., 43ss.

186 Cf. Ibid., 25.

187 Ibid., 53ss. Las cursivas son añadidas.
} 


\subsection{De "monstruos" y "monstruos": Crítica al antitestimonio cristiano}

Otra clave interpretativa de la obra del Nobel de literatura francés es la constituida por la responsabilidad del testimonio cristiano. De hecho, llega a sostener que "el único problema es el comportamiento de los católicos frente a la verdad cuyo depósito han recibido". ${ }^{188}$ En efecto, Mauriac está muy preocupado por las repercusiones de la vida de los seguidores de Jesús en el mundo, es más, se interpela por el papel de los cristianos en la conversión de los pecadores. En otras palabras, reconoce que el mal existe y que nos circunda gente objetivamente mala. Con todo, reserva siempre en el fondo de su corazón la esperanza de la conversión con el auxilio de la gracia divina. Ahora bien, en este estado de cosas los que se llaman cristianos ¿ayudan a los pecadores a encontrarse con Dios o los separan con sus incoherencias vitales? ¿son signos de la presencia del Reino de Dios en el mundo? ¿son instrumentos de Cristo para la conversión de los pecadores?

El propio Mauriac formula esta preocupación en el prefacio que antecede a las obras completas cuando presenta a Nudo de víboras:

Nudo de viboras [...] ilumina una verdad que, durante toda mi vida, he intentado demostrar e imbuir en ciertas mentes preclaras: y es que su mediocridad, su avaricia, su injusticia, y, sobre todo, su mala fe intelectual, todo aquello que constituye el fondo mismo de su naturaleza, crea el necio en torno al Hijo del Hombre que vino a buscar y a salvar lo que estaba perdido. Son ellos los que alejan, desvían de la fuente del agua viva a Irène de Blènauge [protagonista de Lo que estaba perdido] y al anciano [protagonista de Nudo de víboras]. ${ }^{189}$

En Thérèse Desqueyroux aborda la polaridad entre Thérèse - el monstruo por antonomasia-, ${ }^{190}$ y el resto de su familia que, con excepción de tía Clara, eran los verdaderos"monstruos". La novela cuenta la historia de Thérèse, una joven idealista que, lejos de casarse por amor, termina haciéndolo por conveniencia. ${ }^{191}$ Así las cosas, la protagonista es muy desdichada desde la misma noche de bodas, ${ }^{192}$ puesto que tanto a nivel intelectual como sexual se encontraba en las antípodas de su esposo. ${ }^{193}$ Ello hacía que dedicase gran parte de sus esfuerzos vitales en fingir una situación ideal. ${ }^{194}$ No se daba cuenta de que con ese juego la

\footnotetext{
188 Ibid., 33.

189 ID., "Prefacio", en MAURIAC, Obras completas, I, 18.

190 Cf. ID., Thérèse Desqueyroux, 690. 691. 694ss. 643. 690ss. 694.

191 Cf. Ibid., 640ss. 636.

192 Cf. Ibid., 644; cf. Ibid., 645ss.; cf. Ibid., 678ss.

193 Cf. Ibid., 644.

194 Cf. Ibid.
} 
joven Desqueroux se estaba deslizando peligrosamente por un camino sin retorno ya que la vida de apariencia y fingimiento no era una opción para ella. ${ }^{195}$

Todo ello la hundía cada vez más en la soledad, una soledad a la que estaba condenada desde sus propios esponsales. ${ }^{196}$ En el fondo, su vida se resolvía en una farsa que la alejaba de su propia esencia provocando una profunda escisión que la colocaba en una situación bastante difícil. El complejo en el que debatía su existencia la condujo a una situación límite: "yo perdí el sentido de mi existencia individual"197 llegó a sostener agónicamente. A partir de ese momento fue tomando conciencia de que la familia que la rodeaba en verdad no era más que una cárcel. Una cárcel "donde esperaría la muerte" 198 "la secuestrada de Poitiers" ${ }^{199}$ Aún más, Thérèse llegó a considerar su propia existencia como una muerte en vida. ${ }^{200}$ Por eso, solo al final de la novela cuando se desatan los nudos y acaricia su libertad Thérèse puede rebosar de alegría. ${ }^{201}$

Frente a las convenciones sociales del momento, ${ }^{202}$ Thérèse reacciona por la tremenda intentando envenenar a su esposo Bernard, aquel que ponía rostro a su dolor. Ella, agotada de tanto fingimiento, era incapaz de seguir negándose a sí misma, es más, tenía una imperiosa necesidad de reencontrarse consigo misma.

El panorama pintado por Mauriac presenta a una Thérése como prototipo de monstruo odioso que intenta cercenar la vida de su esposo. El acento parece recaer así en la mujer insatisfecha que trata de envenenar a su esposo. Pero, ¿qué hicieron los demás para revertir la situación? Ni Bernard — su esposo- ni el resto de la familia Desqueyroux se habían preocupado jamás de ella. Es más, se llamaban cristianos, pero estaban muy lejos de las máximas evangélicas. Ellos, que pensaban solo en la buena reputación de su familia, así como en sus propios intereses, familiares estaban dispuestos a cualquier cosa. De hecho, estaban

195 Cf. Ibid., 665-669." porque ellos eran ellos, porque yo era yo... Enmascararme, salvar las apariencias, dar el cambio, en ese esfuerzo que imagino que otros seres -que se parecen a mí- perseveraron hasta la muerte, salvados por la costumbre quizá, cloroformizados por el hálito, embrutecidos, adormecidos en el seno de la familia materialista y todopoderosa. Pero yo, pero yo, pero yo...": Ibid., 693.

196 Cf. Ibid., 629; cf, Ibid.,684ss.

197 Ibid., 676.

198 Ibid., 651.

199 Ibid., 707.

200 Cf. Ibid., 661.

201 Cf. Ibid., 710ss.

202 En palabras del propio Bernard: “... solo cuenta la familia. El interés de la familia siempre ha dictado todas mis acciones": Ibid., 688. 
"condenados a vivir en la mentira hasta la muerte". ${ }^{203}$ Estos pequeños monstruos de a pie eran incapaces de comprender y perdonar la forma de ser, así como el pecado de quien no se amolda a sus convenciones socio-religiosas. ${ }^{204}$ Ellos son los "antitipos" que creyéndose practicantes rigurosos de la religión impiden al común de mártires encontrarse con el Dios al que ellos creen imitar. ${ }^{205}$

Ahora bien, si de monstruos verdaderos y falsos hablamos en la producción de François Mauriac hay que hacer referencia obligada a Luis - el viejo de Nudo de víboras - y a su descendencia. A priori, el gran monstruo perfilado en Nudo de víboras es un anciano de 68 años que decide escribir una requisitoria epistolar para su mujer - Isa- donde recoge las amarguras y los reproches de toda una vida. ${ }^{206}$

Por su parte, el Luis que Mauriac pinta reúne en sí muchos de los sentimientos más perniciosos que se puedan llegar a imaginar: odio, ${ }^{207}$ rencor, ${ }^{208}$ avaricia, ${ }^{209}$ codicia, ${ }^{210}$ ambición, ${ }^{211}$ envidia, ${ }^{212}$ ira, ${ }^{213}$ cinismo, ${ }^{214}$ egoísmo, ${ }^{215}$ celos, ${ }^{216}$ tristeza vital, ${ }^{217}$ antipatía, ${ }^{218}$ o infidelidad, ${ }^{219}$ entre otros. A esta pléyade de sentimientos y actitudes negativas se unía el ansia de venganza contra su familia por lo que él consideraba indiferencia respecto del progenitor. ${ }^{220}$ Todo ello anidaba en el corazón de aquel hombre que ejemplifica lo que Mauriac denomina nudo de víboras. ${ }^{221} \mathrm{Tal}$ era el estado de cosas que llegaba a considerarse un ser ajeno a su familia. De hecho, no consideraba a sus hijos y nietos como tales, sino como

203 Ibid., 670.

204 Desde los mismos esponsales la familia Desqueroux solo piensa en modificar el modus vivendi de Thérèse para que se ajustase a los suyos: "Habremos de conducirla rápidamente a las ideas sanas" proclamaba la madre de Bernard: Ibid., 640. cf. Ibid., 642.; cf. Ibid., 693.

205 Cf. Ibid., 679.

206 Cf. ID., Nudo de víboras, 1232.

207 Cf. Ibid., 1229; cf. Ibid.,1241.

208 Cf. Ibid., 1230; cf. Ibid., 1241ss.

209 Cf. Ibid., 1236, et passim.

210 Cf. Ibid., 1292.

211 Cf. Ibid., 1241.

212 Cf. Ibid., 1241; cf. Ibid., 1268; cf. Ibid., 1272.

213 Cf. Ibid., 1244.

214 Cf. Ibid., 1247.

215 Cf. Ibid., 1265.

216 Cf. Ibid., 1234ss.

217 Cf. Ibid., 1239.

218 Cf. Ibid., 1242.

219 Cf. Ibid., 1276ss.; cf. Ibid., 1317ss.

220 Cf. Ibid., 1231.

221 Ibid., 1334. 
adversarios unidos bajo las faldas de su esposa. ${ }^{222}$ Él llega a sintetizar magistralmente su estado: "Mi razón de ser es la maldad". ${ }^{223}$

Así las cosas, la cuestión es quién y cómo lo habían ayudado a tomar conciencia de su situación como punto de inflexión vital. Hemos visto anteriormente como Isa, María y Lucas lo habían rodeado de su amor, pero había algo que lo alejaba instintivamente de Dios llegando a afirmar que"la irreligión no había sido para mí sino una forma vacía donde habían resbalado mis humillaciones de pequeño campesino enriquecido, despreciado por sus camaradas burgueses. Yo la llenaba ahora con mi decepción amorosa y un rencor casi infinito". ${ }^{224}$

Su irreligiosidad era, por tanto, circunstancial y se había consolidado no solo por el "nudo de víboras" que anidaba en su corazón, sino, sobre todo, por medio del antitestimonio de los que debían de ser ejemplos de amor y comprensión. En este sentido, Mauriac pone mucho interés a la hora de describir a los que en principio parecían víctimas del "monstruo", 225 sus hijos - Huberto y Genoveva-, y que, en realidad, eran los grandes monstruos de la novela. ${ }^{226}$ Ellos conocedores de la ley divina y practicantes de la Iglesia católica con su avaricia, sus ruindades y estrategias, sus celos, sus envidias y, sobre todo, con su mediocridad tanto religiosa como humana convierten su corazón en un verdadero "nudo de víboras". En efecto, habían dejado que en su corazón enraizaran los sentimientos perniciosos que criticaban en su padre. Un"nudo de víboras" incapaz de amar y perdonar al padre que arrepentido deseaba recomponer la unidad familiar por medio del vínculo del amor. ${ }^{227}$

Todo ello cataliza, cuando los hijos mayores abrumados por las necesidades económicas tanto propias como de sus respectivas familias descubren que el padre busca la forma de desheredarlos. Es entonces cuando se desatan los nudos de víboras que habían anidado en sus corazones durante toda su vida. Huberto y Genoveva se sienten dispuestos a todo incluso a negar a Luis la noticia de la muerte de su esposa. ${ }^{228}$ Con ello, Mauriac no hace otra cosa que criticar a los cristianos mediocres y timoratos representados por los hijos. Ahora bien, pone mucho

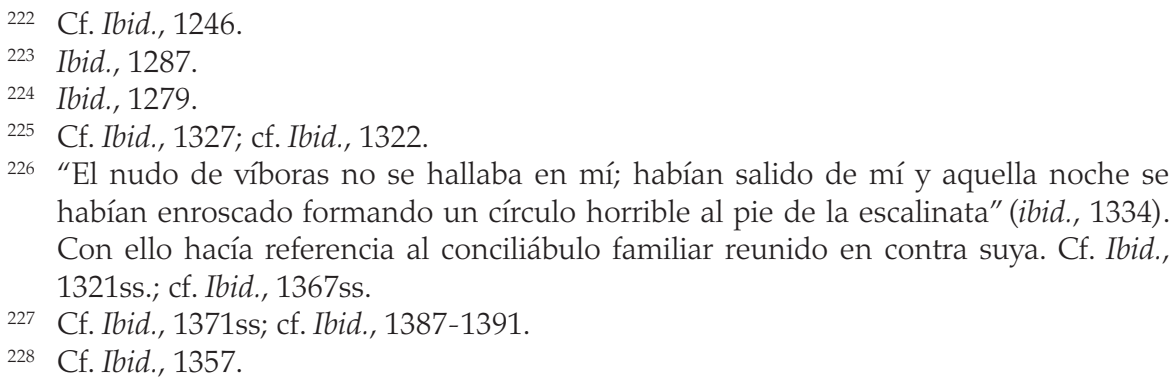


esmero en distinguir entre el contenido y el objeto de la fe cristiana de quien la practica. ${ }^{29}$

Luis era irreligioso y francmasón confeso, es más odiaba todo lo religioso. ${ }^{230}$ Por ello, dedicaba grandes esfuerzos a luchar contra la religiosidad de su familia con sucesivas estrategias: primero, mediante una lucha frontal que fracasa porque tanto su mujer como sus hijos habían ya bebido el veneno de la fe. Después se dedica a buscar las contradicciones vitales de su mujer, contradicciones entre el evangelio y el testimonio concreto. El propio Mauriac lo expresa en la portadilla que hace de antesala a la novela: "... tened piedad de los cristianos mediocres que le acecharon y a quienes él mismo [Luis] atormentó. ¡Cuántos de entre nosotros rechazan así al pecador y le apartan de una verdad que, a través de ellos, no ilumina nada!". ${ }^{231}$

Uno de los más incoherentes es Huberto que a la vez que se cree fiel cumplidor de la Iglesia es incapaz de ver un atisbo de esperanza en el corazón de su padre. Más aún, su actitud sirve de pantalla entre su padre y Dios. De hecho, Mauriac llega a citar Lc 17,2 para confirmar esta idea.

El culmen de la crítica a los cristianos mediocres emerge al final de la obra en la disputa entre Luis y su hija Genoveva a consecuencia de la huida de Phili —novio de Janine- - De hecho, cuando la acorrala por sus incoherencias vitales Luis comenta:

No le gustaba mezclar la religión con esas cosas [con la vida cotidiana]. Era católica militante [...]. Cumplía con sus deberes. Con el mismo tono hubiera dicho que pagaba sus contribuciones. Lo que yo tanto había execrado durante toda mi vida: era eso, nada más que eso; esa grosera criatura, esa carga mediocre de la vida cristiana, y yo había fingido ver en ella una auténtica representación para tener el derecho de odiarla. ${ }^{232}$

Por último, Janine — la nieta— recalca la misma idea a su tío Huberto:

¿No crees que vuestro padre hubiera sido otro hombre si vosotros hubieseis sido diferentes? [...] la desgracia de todos nosotros fue que nos considerara cristianos ejemplares [...] Después de su muerte he tratado a personas que pueden tener sus defectos, sus debilidades, pero que proceden según su fe, que se mueven en plena gracia. Si el abuelo hubiera vivido entre ellos, ¿no habría descubierto, al cabo de tantos años, ese puerto al que no pudo llegar hasta la víspera de su muerte?233

\footnotetext{
229 Cf. Ibid., 1311ss.

230 Cf. Ibid., 1242.

231 Ibid., 1227.

232 Ibid., 1384.

233 Ibid., 1393.
} 
El joven retoño había caído en la cuenta de la diferencia existente entre el gran monstruo y los monstruos de la vida cotidiana ya que "donde estaba nuestro tesoro, se encontraba nuestro corazón". ${ }^{234}$ Pero en el caso del anciano"donde estaba su tesoro no estaba su corazón". ${ }^{235}$ Asimismo, reconoce la incoherencia vital vivida en el seno de la familia pues, "salvo en la abuela, nuestros principios permanecieron separados de nuestra vida. Nuestros pensamientos, nuestros deseos, nuestros actos, no fijaban ninguna raíz en esta fe a la que nos adheríamos con palabras. Nos habíamos consagrado con todas nuestras fuerzas a los bienes materiales, mientras el abuelo...". ${ }^{236}$

Ante este panorama el novelista francés propone una suerte de salida triádica constituida por la fe, el amor y el testimonio. Es decir, el amor entregado a ejemplo de Jesucristo, manifestado en la vida cotidiana de los cristianos debería interpelar y mover a la fe. Así sostiene que "más que ningún otro texto esa Epístola joánica [Dios es amor] debería volver sensible a un incrédulo el secreto de la fe individual, esa relación personal de la creatura con su Creador. La onza de autenticidad que puede contener la vida del cristiano más mediocre se reduce a una onza de ese amor" ${ }^{237}$ De hecho, Mauriac está convencido de que "una vida de santo es una vida de amor". ${ }^{238}$ Frente a las palabras o las buenas intenciones solo el testimonio interpelará a los increyentes. ${ }^{239}$

A partir de ahí y siguiendo las máximas evangélicas Mauriac plantea una especie de revolución de la caridad puesta en práctica de persona a persona. Puesto que las estructuras difícilmente se convierten, es preciso que sean los hombres concretos los que cambien viviendo y experimentado la vida en la caridad. ${ }^{240}$

\subsection{El fariseísmo religioso y su reversibilidad}

Muy ligado al testimonio cristiano se encuentra la crítica al fariseísmo religioso. En este sentido Mauriac llega a sostener que Cristo se aleja

\footnotetext{
234 Ibid., 1394.

235 Ibid.

236 Ibid.

237 F. MAURIAC, La piedra del escándalo, cit., 19.

238 Ibid., 20

239 "Los hombres han sido engañados demasiado: no son las palabras las que hoy actúan sino el ejemplo. [...] el Hijo del Hombre, es el Verbo de la vida, visto, tocado en persona de un pobre viviendo en medio de los pobres y totalmente semejante a ellos en quien, no obstante, resplandece esa presencia ante la cual el ciego de nacimiento cae de rodillas": Ibid., 63.

240 Cf. Ibid., 61ss.
} 
de los fariseos: "Cristo, en términos claros y reiterados, se aleja de los que exclaman: “'Señor! ¡Señor" y no cumplen su voluntad, la voluntad de que nos crucifiquemos con él". ${ }^{241}$ Más aún, para el francés, "esa distancia infinita entre la cruz y la mayoría de las vidas que se proclaman cristianas no es, quizás, menor en muchas personas consagradas a Dios, en aquellas, sobre todo, que no se han entregado totalmente a la multitud como su Maestro, cuyo secreto fue no separar jamás la contemplación de la acción". ${ }^{242}$

No cabe duda de que desde el mismo título de una de sus obras paradigmáticas - La farisea - el fariseísmo emerge como uno de los temas capitales de la producción mauriaciana. Más aún, Mauriac hace una trasposición de la parábola del fariseo y el publicano (Lc 18,9-19) al contexto en que se mueve. ${ }^{243}$ De esta forma, el novelista francés se estaría uniendo a la denuncia del propio Jesús contra aquellos que confían en sí mismos al creerse justos y perfectos (cf. Lc 18, 9) e incluso intérpretes autorizados de la voluntad de Dios. Ello los conduce a situarse en un plano preponderante ante el resto de mortales pecadores a los que intentan reconducir según lo que ellos consideran la voluntad divina.

Para elaborar la trama el autor sitúa a Brigitte Pian, ${ }^{244}$ segunda mujer del Sr. Pian y prima de su anterior esposa, como responsable de la educación de los dos hijos huérfanos. Con todo, ella no se limitará a conducir a los dos jóvenes, sino que se verá impelida a guiar según los designios divinos a todo aquel que la providencia coloca en su camino. Brigitte, mujer extraordinariamente caritativa, ${ }^{245}$ entiende la práctica religiosa como un ejercicio de autoperfeccionamiento en el que se van adquiriendo méritos respecto a Dios, ${ }^{246}$ méritos que habrían de abrir las puertas del cielo para su alma cumplidora. Ella que pasaba por ser"una verdadera cristiana" ${ }^{247}$ y convencida de ser intérprete de la voluntad divina se empeña en conducirse a sí misma y a cuantos la rodean por un camino tortuoso repleto de exigencias y ascesis donde no se encuentra ni rastro de Cristo. ${ }^{248} \mathrm{Tal}$ extremo la lleva a basar la vida en el esfuerzo permanen-

241 Ibid., 22.

242 Ibid., 23.

${ }^{243}$ Cf. ID., La farisea, 743.

244 Cf. Ibid., 683.

245 Cf. Ibid., 731ss.

246 Cf. Ibid., 672; cf. Ibid., 682; cf. Ibid., 708; cf. Ibid., 742ss.; cf. Ibid., 743; cf. Ibid., 744ss.

247 Ibid., 620.

248 La farisea estaba firmemente persuadida de que su vocación "era la de revelar a los demás los propósitos que Dios tenía sobre ellos y que le enviaba a ella desde el fondo de la eternidad": Ibid., 664. Según ella la gracia divina actuaba por medio de sus directrices. Cf. Ibid. En este sentido, "[Brigitte] saboreaba ese placer que solo pertenece 
te, lo cual la desliza inexorablemente a una vida llena de escrúpulos que entenebrecen su corazón y la colocan en el desasosiego permanente. ${ }^{249}$ Ahora bien, "en todas circunstancias Brigitte Pian buscaba el bien, o al menos estaba convencida de que lo buscaba sinceramente" ${ }^{250}$ De hecho, ella confiesa abiertamente que algunas veces se habría podido engañar, pero"Dios es testigo de que siempre he buscado su mayor gloria y el bien de las almas". ${ }^{251}$

En suma, la farisea pone rostro a un tipo de cristianos que, convencidos de hacer la voluntad de Dios, transitan por un camino lleno de escrúpulos que lejos de acercarlos a Dios los alejan de él y los sumergen en una vida angustiosa, extremo este que se hace extensible a cuantos los rodean. En este contexto, las palabras más duras para"una verdadera cristiana" como era la Sra. Pian brotaron de los labios del abate Calou cuando refiriéndose a ella exclamó que "esas son las personas que eligen a Dios, pero a quienes quizás Dios no ha elegido" 252 .

En este estado de cosas, parecía claro que

llegaría un día en que las acciones que había ejecutado [la farisea] la hostigarían volviendo a ella un rostro desconocido y horrible. Pero todavía estaba muy lejos de ese instante y era preciso que muchos sufrieran todavía por su causa antes de que esa mujer tuviera la revelación del amor al que creía servir y que ella desconocía. ${ }^{253}$

Mauriac, convencido de que para Dios no hay nadie perdido definitivamente y de que "el más insignificante tiene un valor infinito", ${ }^{254}$ no abandona a la farisea en una situación religiosa de indigencia, sino que la resitúa en el camino evangélico del seguimiento de Jesús. Un camino de misericordia, de amor y no de cumplimiento de preceptos. De esta forma desaparece en ella la imagen de un Dios "patrón y dueño" que requiere de cada uno de sus fieles un pago escrupuloso. Finalmente ella alcanzó

a Dios que es conocer el destino de alguien que cree descubrírnoslo, y que se siente dueño de inclinarlo en un sentido o en otro": Ibid., 636. En cuanto a la dirección de conciencias baste apuntar "el escándalo Puybaraud" donde pretende extinguir el amor entre la joven Octavie Tronche y el Sr. Puybaraud, un religioso terciario que tenía en gran consideración a Brigitte Pian. Cuando llega a sus oídos el rumor de que iba a abandonar la escuela para casarse con Octavie maquinará todo lo posible para abortar la boda. Cf. Ibid., 637; cf. Ibid., 740ss.

249 Cf. Ibid., 681; cf. Ibid., 731; cf. Ibid., 744ss.; cf. Ibid., 760; cf. Ibid., 779; cf. Ibid., 787.

250 Ibid., 710.

251 Ibid., 758.

252 Ibid., 678.

253 Ibid., 683.

254 Ibid., 670. 
a comprender que lo verdaderamente importante en la vida es amar y dejarse amar: 255

Para Brigitte el interés de la vida había cambiado de sitio. El tejido de falsa perfección en el que ya no trabajaba le dejaba, de ahora en adelante, el ocio de contemplar a los demás y observar ese extraño juego llamado amor que ellos jugaban y al que ella misma había servido con horror, y durante tantos años, sin tratar de descubrir el misterio que encierra esa palabra. ${ }^{256}$

Este cambio hacia el crepúsculo de su vida entronca con la idea mauriaciana según la cual“Dios es la buena tentación a la cual muchos sucumben por último". ${ }^{257}$ Un proceso este de conversión que habría sido fruto de una conjunción de elementos catalizados por la gracia divina. ${ }^{258}$ Por un lado, la acción del abate Calou que, en cuanto ella se dejó conducir, ${ }^{259}$ la orientó por el camino del evangelio. En efecto, él la interpeló a dejar de inmiscuirse en la vida de los demás para adentrarse en su corazón y encontrar allí la fuente y los secretos del amor que ella había creído conocer. ${ }^{260}$ El propio narrador cuenta cómo

255 Cf. Ibid., 810.

256 Ibid., 798.

257 Ibid., 797.

258 En palabras del propio sacerdote ante las diversas situaciones de la vida"indudablemente la gracia se ha aprovechado de ello, porque tal es el amor de Dios que para aquellos a quienes ama todo lo transforma en el más grande bien": Ibid., 785. La propia farisea también "hablaba de la providencia a quien hay que confiarse, que no nos abandona jamás y que nos sigue con amor en los momentos más duros y cuando nos creemos abandonados": Ibid., 673. Por otro lado, la misma farisea era consciente de que "en lo más hondo de sí misma, en algunas ocasiones [...] algunos resplandores desgarraban las tinieblas por encima de su alma y entonces, de pronto, conseguía verse a sí misma. Con una evidencia cegadora [...] descubría que existía otra vida distinta de la suya y otro Dios distinto del suyo": Ibid., 744.

259 Cf. Ibid., 789.

260 "He tenido la audacia [escribía en su diario el abate Calou] de ponerla en guardia contra esta interpretación temeraria del deseo divino de que abusan demasiadas personas piadosas. [...] A Brigitte le interesa menos comprender nuestro pensamiento que retener de él lo que cree que puede inducirnos a error ante la autoridad e incluso a perdernos": Ibid., 714ss. El propio clérigo le reconoce al pequeño Louis que él había cometido el mismo error que la farisea: "quizá le asombraría que le dijera que, por diferentes caminos, mi error se ha unido al suyo: uno y otro, ella con su sola razón y yo con mi corazón, hemos creído que nos correspondía intervenir en el destino de los demás.Y sin duda lo esencial de nuestro ministerio, como deber de todo cristiano, es proclamar el evangelio; pero esto no sería capaz de transformar al prójimo según nuestra manera de ser y según nuestros puntos de vista particulares, porque nada podemos por nosotros mismos, y solo podemos ir ante la gracia como el perro precede al cazador invisible, con más o menos eficacia según prestemos mayor o menor atención a la voluntad del Maestro y seamos indiferentes a la nuestra": Ibid., 784ss. 
bajo la influencia de los consejos del Sr. Calou, vimos su derrumbamiento y la búsqueda de las fuentes de una religión interior. Pero lo que ella iba a suprimir de su vida era precisamente todo aquello que, a sus ojos, había constituido su religión: todo lo que satisfacía su afán de dominación, de dirigir y de no doblegarse a nada en bien de la pureza o de la perfección. ${ }^{261}$

Con todo, en la nueva situación, el sacerdote le suplicó" que se penetrara de su propia insignificancia y de no sustituir la ilusión de haber sido una persona muy avanzada en la vida de perfección, por la de creerse una pecadora insigne", 262 lo cual habría seguido siendo, cuanto menos, soberbia espiritual.

Por otro lado, en el atardecer de la vida conoció el amor humano ${ }^{263}$ que debía de ser signo del amor divino. ${ }^{264}$ Más aún, fue el amor de un anciano protestante - el Sr. Gellis, con pocas características que lo destacasen por su belleza y atractivo- ¿ ¿Quién le iba a decir a ella que el Señor iba a tocar su corazón por medio de alguien ajeno a su práctica religiosa? Pues bien, "el querido Sr. Gellis [...] conducía a Brigitte a la calma del Señor" ${ }^{265}$ Lo que para cualquiera podría haber sido visto como algo burlesco e irrisorio fue empleado por la providencia para hacer experimentar a Brigitte lo que le había indicado el abate: la profundidad del corazón humano tan necesitado de amor. A partir de ahí pudo descubrir que en la vida lo importante no es tener"méritos" ante Dios, sino cuánto se ame.

Todo ello lo sintetiza el literato francés en el alegato final de Louis sobre su madrasta a modo de colofón que hace las veces de moraleja o de enseñanza final:

Brigitte no escurría el bulto cuando yo aludía a acontecimientos del pasado; pero comprendí que se había desasido incluso de sus pecados y que se abandonaba enteramente en manos de la misericordia. En el atardecer de su vida, Brigitte Pian había descubierto, por fin, que no es preciso ser semejante a un servidor altivo y cuidadoso de deslumbrar al amo, pagándole su deuda hasta el último céntimo, y que nuestro Padre no espera de nosotros que seamos los contables minuciosos de nuestros propios méritos. Ella sabía ahora que no hay que merecer, que lo que importa es amar. ${ }^{266}$

\footnotetext{
261 Ibid., 797.

262 Ibid., 791.

263 Cf. Ibid., 808; cf. Ibid., 805.

264 Cf. Ibid., 810.

265 bid., 808.

266 Ibid., 810.
} 
A pesar de todo, Mauriac conoce la condición débil del hombre confirmando la profecía del párroco de Baluzac. ${ }^{267}$ Por eso, a pesar de la profunda conversión Brigitte seguía siendo una pobre pecadora como el resto de los marcados por el signo de Adán. ${ }^{268}$

\section{A MODO DE CONCLUSIÓN}

Tras asistir al despliegue del núcleo esencial de la obra de François Mauriac hemos contemplado que fue un hombre de su tiempo siempre preocupado por las cuestiones que se encontraban en el ambiente tanto cultural como social. Dicho con otras palabras, en el novelista francés no encontramos un sistema arquitectónico al estilo kantiano, ni siquiera un desarrollo teológico, sino una literatura encarnada con una eminente componente práctica. De esta manera, podemos afirmar que la aportación del premio Nobel de literatura consiste principalmente en un fértil pensamiento puesto al servicio de la defensa de los principios religiosos.

En este contexto, uno de los problemas concretos a los que Mauriac intentó responder fue el "misterio del mal" y su posible impugnación de la existencia de Dios. Íntimamente unido a este, intentó salir al paso de otro de los problemas de la sociedad de su época: la corrupción y la degradación moral del hombre que, según él, hundía sus raíces en la progresiva secularización de la sociedad. De hecho, el literato francés dedicó gran parte de sus esfuerzos tanto a luchar contra estos fenómenos como a defender los rudimentos básicos de la fe católica, pues para él no eran más que las dos caras de la misma moneda.

Ahora bien, para Mauriac la apologética no consistía solo en hablar bien a favor de la religión. De hecho, como hemos constatado, critica aspectos esenciales de la vida cristiana como el antitestimonio o el fariseísmo.Tampoco suponía una defensa sin más apoyos que la vehemencia de principios indefendibles. Mauriac concebía la apologética como una dar razón de la fe y de la religión por medio de experiencias vitales suscitadas a través de unos "monstruos" y de unas "víctimas mártires". Los primeros son los llamados a descubrir en sus míseras condiciones la mano de su Creador que actúa a través de los segundos. Así, por medio de una especie de apologética pedagógica el premio nobel intenta transmitir sus convicciones religiosas en sus lectores.

\footnotetext{
267 Cf. Ibid., 791.

268 "No quería decir esto que la farisea hubiese muerto en ella; la lucidez que le había permitido juzgarse y condenarse, la había hecho altiva. No creía que pudieran citarse muchos ejemplos de una cristiana capaz de reconocer, a los cincuenta años, que había seguido un camino equivocado": Ibid., 800.
} 
La historia del pensamiento había dejado insoluble el problema del mal respecto de la existencia de Dios. Ello había catalizado en una teodicea que intentaba por todos los medios encontrar una salida a la cuestión atribuida a Epicuro. Los esfuerzos eran vanos mientras siguiéramos situándonos en el único plano de la razón. François Mauriac intenta dar una salida al problema del mal desde el ámbito de la caridad por medio de sus "monstruos" y de las "víctimas-mártires" a través de las cuales la acción divina actuaba en ellos. De hecho, a partir de la doctrina tradicional del mal — debido a la libertad del hombre - el literato francés reelabora su desarrollo de manera racional, comprensible y legítima a los ojos de una sociedad secularizada. Él partía de la experiencia concreta, una experiencia que podía haber sido sufrida por cualquier mortal. Por eso, la propuesta de Mauriac es muy sugerente ya que podía comprender el leit motiv de cualquier desarrollo vital. En efecto, aunque el novelista francés en su búsqueda de una solución a la aporía de la razón incurriese en un cambio de planos —-filosóficamente ilegítimo-, su salida podría ser aceptada por el común de mortales al entroncar con su experiencia vital.

Giovanni Giorgio afirmaba recientemente que "el Cristianismo es para el mundo, no para sí mismo, y cuanto más escuche al mundo tanto más podrá modular el anuncio de salvación para que sea oído por el mundo"269. En cierto sentido, esta es precisamente la tarea que procuró consumar Mauriac. Él no se mantuvo impasible ante el mundo secularizado que le tocó vivir ni pretendió permanecer enrocado en sistemas tradicionales de evangelización. Al contrario, intentó escuchar al complejo mundo que le rodeaba con sus cuestionamientos e inquietudes, con el fin de entablar un diálogo con él en busca de nuevas soluciones evangelizadoras: unas propuestas que, enraizadas en la esencia del Cristianismo, fuesen capaces de incidir en la sociedad contemporánea.

269 Giovanni Giorgio (dir.), Dios: la posibilidad buena. Un coloquio en el umbral entre filosofía y teología: Gianni Vattimo y Carmelo Dotolo, Barcelona, Herder, 2012, 26. 